\title{
Chemical weathering and runoff chemistry in a steep headwater catchment
}

\author{
Suzanne Prestrud Anderson ${ }^{1 *}$ and William E. Dietrich ${ }^{2}$ \\ ${ }^{1}$ Institute of Tectonics, Department of Earth Sciences, University of California, Santa Cruz, Santa Cruz, CA, USA \\ ${ }^{2}$ Department of Earth and Planetary Sciences, University of California, Berkeley, Berkeley, CA, USA
}

\begin{abstract}
:
We present here deductions about the location, rate, and mechanisms of chemical weathering in a small catchment based on a catchment-scale sprinkling experiment. In this experiment demineralized water was applied at an approximately steady rate in the CB1 catchment in the Oregon Coast Range to reach and maintain a quasi-steady discharge for a period of 4 days. Because of nearly steady flow conditions within the catchment, the contribution to solute fluxes from soil and bedrock could be partitioned. One half of the solute flux from the catchment derived from colluvial soil, and one half from weathering in bedrock. This implies more intense weathering in the thin colluvium mantling the catchment than in the thick underlying weathered bedrock. The annual solute flux from the catchment, scaled to the annual runoff from the catchment, is $32 \pm 10 \mathrm{t} \mathrm{km}^{-2}$ year $^{-1}$, equivalent to published chemical denudation rates for nearby rivers with drainage areas $10^{6}$ times greater than the experiment site. Soil waters sampled during the sprinkling experiment had steady compositions following a period of transient water flow conditions, implying steady-state chemical evolution in the soil. The waters leached 'organic' anions from shallow depths in the soil, which solubilized aluminium and iron, indicating that podzolization is occurring in these soils. Carbonate dissolution appears to be an important source of solutes from the bedrock, despite being present as only a minor phase in the rock. Water balance suggests that the residence time of water in the catchment is about 2 months, and that typical $24 \mathrm{~h}$ storms displace only a fraction of the stored water. A consequence is that runoff chemistry is dominated by old water, which imposes strong limits on the variability of runoff composition. Copyright (c) 2001 John Wiley \& Sons, Ltd.
\end{abstract}

KEY WORDS chemical weathering; flow paths; chemical denudation; soil water; field experiment

\section{INTRODUCTION}

Catchments are readily characterized as black boxes. There is a known input (rain water) and a known output (runoff), yet the relationship of one to the other is a matter of considerable speculation (Beck et al., 1990). The convolution of the input with the processes inside the black box to produce the output is yet more complicated when dissolved constituents are of interest, as both the movement of water and its geochemical evolution must be divined throughout the catchment. Despite these difficulties, the chemistry of runoff is of interest because it contains evidence of chemical denudation of the landscape and of soil-forming processes. The chemistry of runoff holds the keys to understanding the location and tempo of chemical weathering.

Here, we peek inside the black box of the CB1 catchment, a small headwater catchment in the Oregon Coast Range, bringing to bear previous work on the catchment hydrology and extensive observations of soil water and runoff chemistry. In the CB1 catchment, we have a uniquely well-constrained system. The bedrock geology is simple. The catchment is small enough that, in collaboration with others, we have been able to conduct catchment-wide sprinkler experiments, and to collect from a dense network of soil water and runoff sampling sites. Our goals in this well-constrained system are to pinpoint where the solutes in the runoff are derived, and to document the evolution of water moving through the catchment. These observations allow us

* Correspondence to: S. P. Anderson, Institute of Tectonics, Department of Earth Sciences, University of California, Santa Cruz, Santa Cruz, CA 95064-1077, USA. E-mail: spa@es.ucsc.edu 
to draw conclusions about the rate of chemical denudation, the processes of soil formation and the temporal evolution of runoff chemistry.

Catchment studies of weathering have generally focused on weathering rates within the catchment as a whole, rather than identifying where in the catchment the processes occur (Drever and Clow, 1995; Trudgill and Wise, 1997). In a seminal analysis of weathering processes in the Sierra Nevada, Garrels and Mackenzie (1967) compared weathering in ephemeral springs, representing shallow, short-contact paths, with perennial springs, representing deep, long-contact time paths. They found that the deeper flow path was best explained by plagioclase weathering to smectite and a small amount of calcite dissolution, whereas the shallow flow path could be attributed to feldspars weathering to kaolinite. In a detailed study of weathered profiles in the Virginia Piedmont, Pavich (1986) concluded that weathering processes were most active at the base of the saprolite, where the weathering front is advancing down into fresh rock. Studies of soil profile development give the clearest picture of where weathering processes are localized. The accumulated effects of weathering are greatest in the A, E and B horizons of soils (Birkeland, 1999). The thickness of C horizons (i.e. slightly altered parent rock) may be fairly great, however, and have the potential to be important sources of solutes. Miller and Drever (1977), for instance, found that slight alteration of large volumes of bedrock accounted for the stream chemistry in the Absaroka Mountains, Wyoming.

To address questions about the rate and location of chemical weathering, we used not one but several methods to illuminate the black box. The salient features of our experimental design include (1) the sprinkling experiments were carried out long enough for approximate steady-state hydrologic conditions to be attained, (2) the water applied was demineralized to very low solute concentrations, its chemistry closely approximating that of natural rainwater, (3) the catchment is simple lithologically, and is well characterized in both its soil and bedrock constituents, and (4) tracer studies (Anderson et al., 1997a) allow determination of flow paths through the catchment. We report two types of data, the first being concentration profiles taken within soil lysimeter nests, whose evolution is documented on a daily basis, the second being fluxes at two weirs at the base of the catchment that are considerably more closely spaced in time.

Taken together, the data sets we present here allow us to address long-standing issues in catchment hydrology and chemistry, as well as geomorphic questions associated with soil formation within the catchment. In particular, we constrain how much of the new rain water makes its way through the catchment in a storm, and how much of the discharge is old water that has therefore remained in chemical contact with the catchment soil and bedrock for substantially longer periods of time. This will be relevant to the issue of the origin of the inverse concentration-discharge relationship (Anderson et al., 1997b). The chemistry of soil solutions within the experiment bears upon the issue of the relative importance of chemical and physical processes in soil evolution. Finally, the solute fluxes from the catchment with known rainfall and solute influxes allow calculation of denudation for the sprinkling experiment. By appropriately scaling up to an annual basis through knowledge of the annual discharge, we estimate catchment denudation rates for comparison with rates derived entirely independently.

We first describe the hydrology, specifically the rates and trajectories of water movement through the catchment, followed by a description of the chemistry of the water through the system. We begin with the rainfall chemistry, and then present an overview of total solute loads in the soil water and runoff, which allow the partitioning of solute sources in the catchment. Then we show the detailed evolution of water as it moves through the soil, ending with the detailed time series of runoff chemistry.

\section{FIELD SITE}

Our experiment was conducted in the steep, unchannelled CB1 catchment (Figure 1) located on Mettman Ridge in the Oregon Coast Range. The $860 \mathrm{~m}^{2}$ catchment slopes $43^{\circ}$ on average and forms the entire contributing area to an ephemeral first-order stream. Organic-rich colluvial soil on the slopes blankets the sandstone bedrock. The colluvium is $1.5-2.0 \mathrm{~m}$ thick down the axis of the unchannelled valley, as shown in the longitudinal 


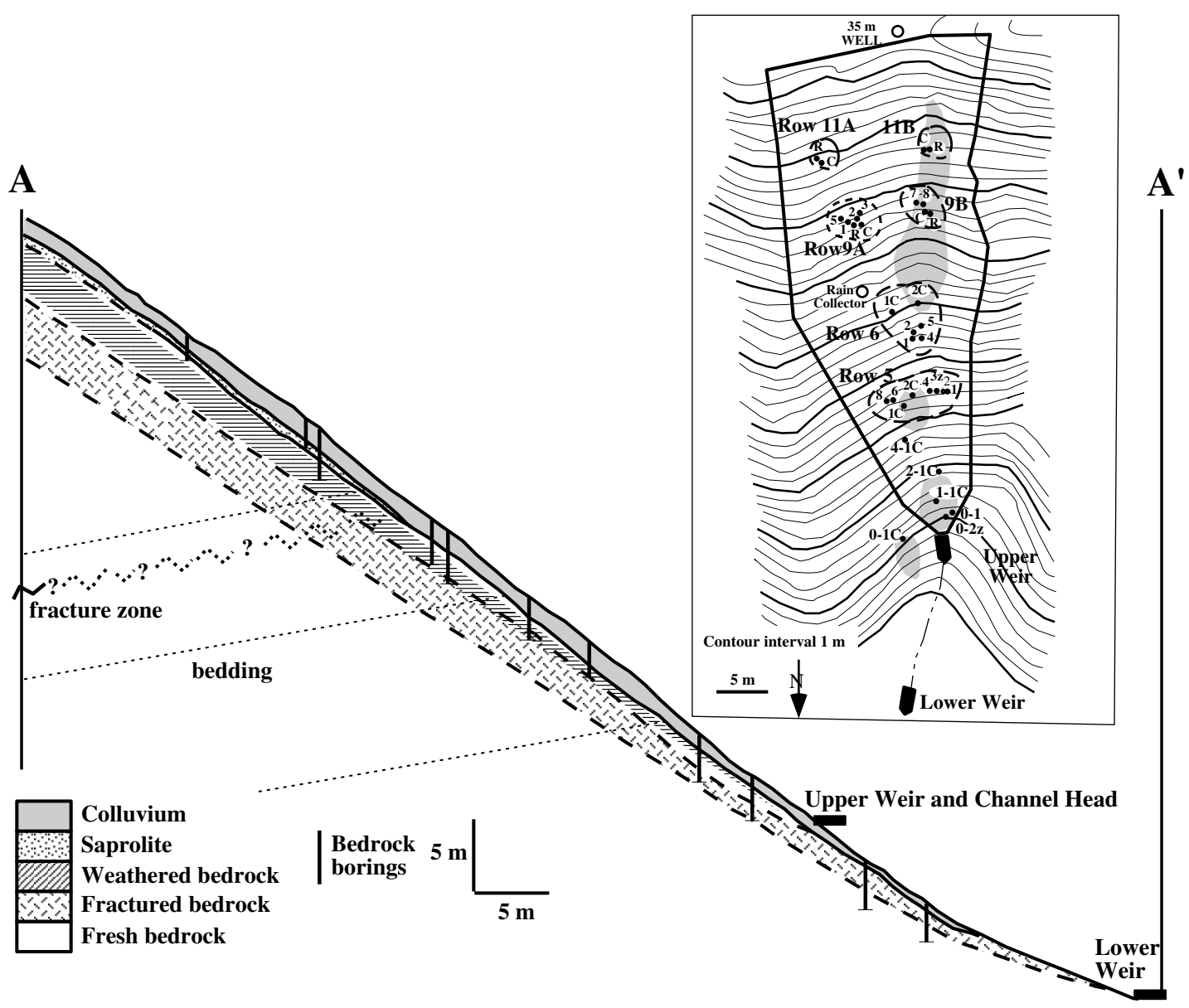

Figure 1. Geologic cross-section and map of the CB1 catchment on Mettman Ridge in the Oregon Coast Range. The subsurface geology is constrained by bedrock borings within the catchment and the $35 \mathrm{~m}$ core at A on the diagram. Inset shows lysimeter locations. Nests of lysimeters are circled with dashed lines. Lysimeters labelled C or R are ceramic cup design; those labelled $\mathrm{z}$ are zero-tension lysimeters. The remainder are constructed of polyethylene plates. Lysimeters labelled $\mathrm{R}$ are augered into saprolite, and those labelled $\mathrm{C}$ are at the colluvium-bedrock interface. All others are in colluvium. Shaded areas on inset (from Montgomery (1991)) show where subsurface saturation developed within the colluvium during the experiment. Topography was not mapped near the lower weir

profile in Figure 1, and thins toward the edges of the catchment, describing a steeply inclined teardrop-shaped body of colluvium over fractured and weathered bedrock. The site supported a coniferous forest cover until it was logged in 1987. It was planted with Douglas fir (Pseudotsuga menzeisii) in 1988 after an application of herbicide. Alder trees and blackberry vines were hand-cut from the site in the days prior to the May 1992 sprinkling experiment described here. The dynamics of runoff generation, vadose zone flow, and landslide initiation at this site are discussed in other papers (Montgomery et al., 1997; Torres et al., 1998).

The bedrock at the site is Eocene age Flournoy Formation, a greywacke sandstone (Baldwin, 1974, 1975). In a $35 \mathrm{~m}$ core obtained at the drainage divide at the top of the catchment, weathered rock extended $9 \mathrm{~m}$ below the surface. Sandstone dominated the core; shale and pebble conglomerate layers comprise no more than $1.5 \mathrm{~m}$ of the section. According to Baldwin (1974) and Dott (1966), the mineralogy of the Flournoy is indistinguishable from other Eocene greywackes of the Oregon coast, such as the Tyee and Coaledo Formations. Dott (1966) reports compositions for these rocks of $29-47 \%$ quartz and chert, $12-26 \%$ feldspar, about equally divided between plagioclase and K-feldspar, and 19-30\% volcanic rock fragments, whereas Lovell (1969) reports 15\% 
quartz, $18 \%$ feldspar, of which two-thirds is plagioclase and one-third is K-feldspar, and $20 \%$ volcanic fragments in the similar Tyee Formation. Point counts of three unstained thin sections of fresh sandstone from the $35 \mathrm{~m}$ core at the CB1 catchment yielded 40-52\% quartz, 13-19\% feldspar, and 7-14\% lithic fragments. The use of unstained thin sections puts the quartz and feldspar numbers in serious question; nonetheless, the mineralogy is similar to that obtained by Dott (1966) and Lovell (1969), namely rich in easily weatherable feldspar and volcanic fragments. Carbonate cement occurs spottily in the rock; in our $35 \mathrm{~m}$ core, carbonate cemented portions accounted for only $4 \%$ of the length of the core and was additionally associated with fractures.

Weathering of the bedrock has produced three distinct layers subparallel to the ground surface. These layers have been mapped (Figure 1) on the basis of the $35 \mathrm{~m}$ core and several small cores obtained with a modified portable power auger (MacDonald, 1988). The density of open fractures decreases downcore. Layers are identified based on strength and oxidation. A thin layer of saprolite, defined as rock penetrable with a hand auger, underlies the colluvium in the upper part of the catchment. Pervasively oxidized rock underlies the saprolite and continues downslope as far as the channel head, where the upper weir is located. The deepest layer of weathered rock is characterized by bands of oxidized rock a few tens of millimetres thick around the open fractures; this layer appears to thin downslope.

The soil in the CB1 catchment is a colluvial accumulation of material derived from the underlying sandstone bedrock, mapped as Haplumbrepts by the Soil Conservation Survey (Haagen, 1989). Its texture is sandy-gravelly, and carbon contents range from 1.3 to $4.6 \%$ by weight (Figure 2). Colluvium bulk density ranges from $(0.7$ to 0.8$) \times 10^{3} \mathrm{~kg} \mathrm{~m}^{-3}$. Porosities of $0.6-0.7$ have been measured (Torres, 1997; Anderson, 1995). In this work, a value of 0.7 will be used in calculations.

The mineralogy does not vary much between the bedrock layers (Anderson, 1995). Feldspars show a modest decline in abundance and reddish groundmass increases from parent rock to the pervasively oxidized layer.

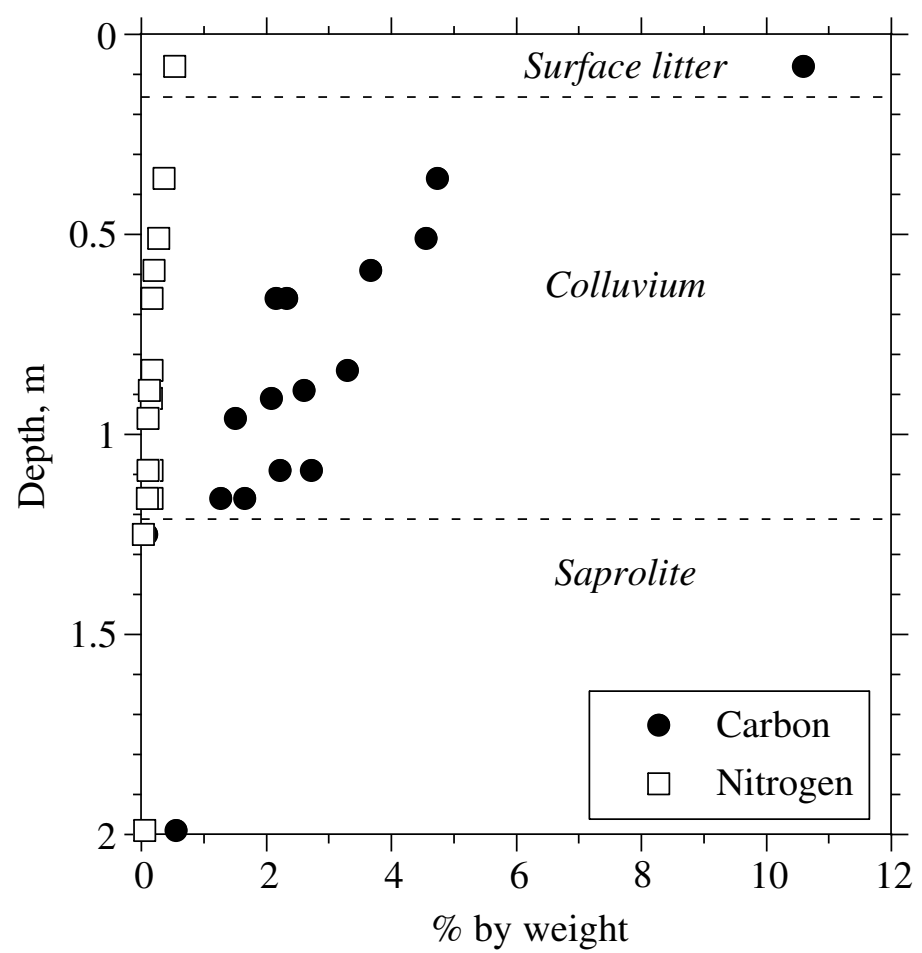

Figure 2. Carbon and nitrogen contents (weight percent) in samples from two soil pits in the CB2 catchment (see Figure 1 for location). A radiocarbon age of $4070 \pm 90$ B.P. (CAMS, LLNL) was obtained from charcoal at the base of one of these soil pits 
The soils, however, are depleted in quartz and feldspars, and all grains show pitting or embayments. Carbonate cement was not found in the weathered rock layers or soil.

\section{EXPERIMENTAL DESIGN}

During sprinkler experiment 3, conducted in May and June of 1992, rotating pulse-type sprinklers delivered water to the entire CB1 catchment (Figure 3). This was a long-duration, approximately steady-intensity sprinkling experiment. Experiments 1 and 2, one of which was similar in intensity and duration to experiment 3 and one of which was of higher intensity, are discussed in Anderson et al. (1997b), Montgomery et al. (1997) and Torres et al. (1998). For experiment 3, the sprinklers ran continuously from 10:00 on 27 May 1992 through to $08: 15$ on 3 June 1992, a total of 7 days, and intensive monitoring continued for an additional 2 days. The average rainfall rate was $1.65 \pm 0.77 \mathrm{~mm} \mathrm{~h}^{-1}$, measured in 102 wedge gauges within the catchment.

The rainfall was approximately steady: on-shore breezes caused a diurnal variation in rainfall intensity of roughly $0.4 \mathrm{~mm} \mathrm{~h}^{-1}$. This produced discharge fluctuations throughout the sprinkling experiment. After 3 days of sprinkling, the nearly monotonic rise in discharge gave way to a period of diurnally oscillating discharge that was maintained for 4 days. Hereafter, this period of diurnally oscillating discharge will be referred to as the period of steady discharge or steady flow conditions, with the understanding that daily fluctuations did occur. The total discharge during the steady flow period was $1.06 \pm 0.15 \mathrm{~mm} \mathrm{~h}^{-1}(n=43)$, or $64 \%$ of the rainfall rate.

Runoff from the catchment was monitored in two independent weirs (Figure 1). The upper weir was located at the channel head. Water from the upper weir was routed around the lower weir, located down channel approximately $15 \mathrm{~m}$ from the upper weir. About half of the total discharge from the catchment emerged at the upper weir. Discharge was monitored automatically at $10 \mathrm{~min}$ intervals with a stage recorder, as well as

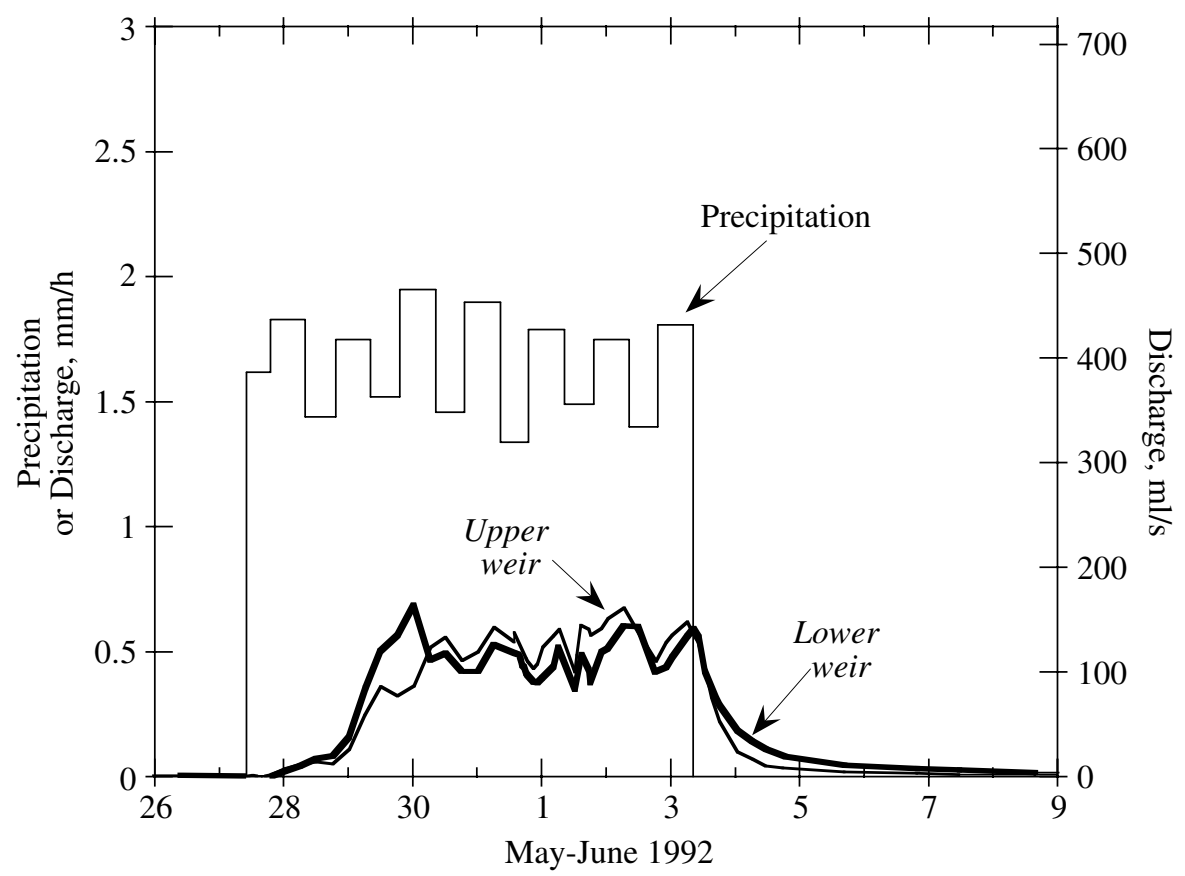

Figure 3. Rainfall and runoff rates during sprinkler experiment 3. The rainfall rates shown are catchment averages based on 102 wedge gauges within the catchment, read twice each day. The specific discharge is based on a catchment area of $860 \mathrm{~m}^{2}$. Note that the total runoff from the catchment is the sum from the upper weir and the lower weir 
by hand at a minimum of $6 \mathrm{~h}$ intervals with a graduated cylinder and a stopwatch. The hand measurements, which are more sensitive to small changes in discharge and are more accurate at low discharges, are shown in Figure 3. TW Giambelluca Personal Communication (1993) measured and calculated an average evaporation rate of $0.27 \pm 0.05 \mathrm{~mm} \mathrm{~h}^{-1}$ from the site during experiment 3 . Thus, deep leakage may account for as much as $0.32 \mathrm{~mm} \mathrm{~h}^{-1}$ during the steady discharge portion of the experiment.

The total rain applied during the experiment was $274 \pm 102 \mathrm{~mm}$, an amount slightly greater than the amount of water stored in the colluvium before the experiment. The average colluvium depth of $0.7 \pm 0.4 \mathrm{~m}(n=104)$ and water content before sprinkling began of $0.19 \pm 0.05 \mathrm{~m}^{3} \mathrm{~m}^{-3}$ (Torres, 1997) implies that initial water storage was $133 \pm 100 \mathrm{~mm}$ in the colluvium.

The advantage of the constant, long-duration rainfall of experiment 3 is that, after an initial wetting period, flow through the catchment is relatively steady and uniform, which simplifies analysis. Once steady discharge conditions are achieved, flow and water content in the subsurface is essentially steady (Montgomery et al., 1997; Torres et al., 1998) and changes in soil water and runoff chemistry can be attributed to chemical rather than flow processes. We make considerable use of the steady flow conditions to determine solute sources and follow water chemical evolution.

Water for the sprinkling experiments was trucked from a pond located $2 \mathrm{~km}$ from the catchment. The water was demineralized before entering the sprinkler lines by passing it through a $10 \mu \mathrm{m}$ particulate filter and an activated carbon filter before going through a series of anion, cation, and mixed-bed ion exchange tanks. The goal of demineralization was to produce solute-free water closer in character to natural rains of the Oregon coast than the pond water. Demineralization also permitted comparison of the runoff chemistry produced during experiment 3 with that from similar duration sprinkling experiments conducted with untreated water in 1990.

\section{Water sampling}

Soil water samples were collected with 34 lysimeters distributed in six nests and scattered isolated installations within the catchment (Figure 1). Sixteen of the samplers were built with ceramic cups (Soil Moisture, 0.5 bar high-flow), 16 were manufactured with polyethylene plates, following the design of Driscoll et al. (1985), and two zero-tension samplers consisted of Teflon-chip filled high-density polyethylene (HDPE) storage containers. Water flowed continuously from one of these zero-tension samplers $(0-2 z)$ during the experiment, permitting instantaneous sampling of the soil water at that location. All of the lysimeters were installed in May 1991, one year before experiment 3.

All samplers were placed within colluvium, except the samplers designated ' $R$ ' in rows 9A, 9B, 11A and $11 \mathrm{~B}$, which are ceramic cup-type samplers in holes augered into saprolite. These installations were not sealed, however, and therefore probably sample a mixture of water from soil and from saprolite. Though most of the samplers were located in the vadose zone within the colluvium, several were deep enough to experience saturated conditions. Four samplers, $0-1,0-2 \mathrm{z}, 0-1 \mathrm{C}$, and $1-1 \mathrm{C}$, were located in a thin layer of saturation that develops near the upper weir in the colluvium during storms, and samplers $C$ and $R$ in rows $9 \mathrm{~B}$ and $11 \mathrm{~B}$ were within a thin layer of saturation that develops at the base of the colluvium in the hollow axis during storms (Figure 1).

A vacuum of $63.5 \mathrm{~mm} \mathrm{Hg}$ was supplied to the tension samplers with a battery-operated pump. Lysimeter samples were collected each morning during the experiment after applying suction for 8 to $10 \mathrm{~h}$ starting at midnight. Difficulties with the vacuum pump on 1 June, the fourth day of experiment 3, resulted in low sample recovery that day. After sprinkler shutdown on the morning of 3 June, the vacuum pump was run continuously, and samples were collected three additional times over the next $36 \mathrm{~h}$. Samplers $0-1$ and $2 \mathrm{C}$ in the row 6 nest were exceptionally efficient collectors and were opened to vacuum about $2 \mathrm{~h}$ before sample collection.

Although the suction applied with the vacuum pump was significant relative to the pressure head in the soil, we feel that the samples collected were representative of the water moving in the soil. Approximately half the 
pore space in the soil is characterized as macroporous (Torres, 1997) using the Luxmoore (1981) classification. Under the steady flow conditions during the sprinkler experiments, the soil was near saturation and presumably most flow was through these macropores. Samples from zero-tension lysimeters were chemically similar to those from nearby suction lysimeters.

Water samples were collected manually at the two weirs every $6 \mathrm{~h}$ through experiment 3 . Precipitation was collected twice daily from a bottle equipped with a funnel, both made of HDPE. The opening to this collector stood about $0.5 \mathrm{~m}$ above the ground surface.

\section{Chemical analysis}

Measurement of $\mathrm{pH}$ and filtration of water samples was done in a portable laboratory on site, usually on the day of sample collection. Sample $\mathrm{pH}$ was measured with an Orion Ross Sure-flow combination electrode on an unfiltered aliquot. Another unfiltered aliquot was set aside for later measurement of alkalinity. The remaining sample was filtered $(0.45 \mu \mathrm{m})$. One filtered aliquot was acidified with concentrated ultrapure nitric acid and stored in a nitric-acid-washed HDPE bottle. A second filtered aliquot was stored without acidification in a deionized water-washed HDPE bottle. Sample blanks were prepared by filtering a sample of distilled water each day in our field laboratory. Samples were stored in a cold room at $4{ }^{\circ} \mathrm{C}$ from within 2 or 3 days of their collection until the time of analysis. Because of small sample size, the chemical analysis for some lysimeter samples is incomplete.

Alkalinity titrations were conducted on stirred, unfiltered samples using the Gran method (Gran, 1952; Stumm and Morgan, 1981). The same Orion Ross Sure-flow combination electrode used for $\mathrm{pH}$ measurement was used along with a Hach digital titrater. These analyses were completed 1 year after the end of the experiment.

The anions chloride, bromide, nitrate and sulfate were analysed on filtered non-acidified samples by ion chromatography (Dionex). Fluoride, nitrite, and phosphate were not detected. All but the most dilute samples were diluted by $1 / 6$ with deionized water before analysis. Duplicate samples and replicate runs showed that values were reproducible to within 0.2 ppm (Anderson, 1995). All Dionex analyses were accomplished within 6 to 11 months after the sprinkling experiment.

Calcium, magnesium, sodium, potassium, aluminium, iron and silica were analysed on filtered acidified samples with inductively coupled plasma-atomic emission spectrometers (ICP-AESs). Most of the samples were analysed on an ARL Fisons 3560 simultaneous collector ICP-AES located at the Lawrence Berkeley Laboratory (LBL). About $20 \%$ of the samples were analysed on a Perkin Elmer sequential ICP-AES located at the University of California, Santa Cruz (UCSC). The ARL Fisons 3560 analyses were completed between 12 and 14 months after the experiment, whereas the Perkin Elmer measurements were completed 24 months after the experiment. Samples analysed on both machines agree to within 5\%, except aluminium, which differed by a factor of two between the machines. Replicate analyses and duplicate samples show that values were reproducible to within $0.2 \mathrm{ppm}$ (Anderson, 1995). Concentrations of calcium, sodium, magnesium, potassium, and iron in a standard riverine water reference material, SLRS-2, measured on the Perkin Elmer ICP-AES were within $10 \%$ of the certified values, and aluminium was within $12 \%$ of the certified value (Anderson, 1995).

The charge balance obtained in samples of runoff, precipitation, and the steadily flowing zero-tension sampler $0-2 \mathrm{z}$ were $7 \pm 3 \%$, with positive charge nearly always in excess. The imbalance of charge in soil water samples (other than from sampler 0-2z) was much greater, and provided an estimate of the organic anion component of the soil solution (Dahlgren and Ugolini, 1989). We noted a visual correlation between sample colour and the magnitude of the negative charge deficit in soil water samples, supporting this interpretation.

\section{FLOWPATHS}

Water flow routes through the CB1 catchment have been identified with piezometric and tensiometric measurements during natural storms and sprinkling experiments (Montgomery et al., 1997; Torres et al., 
1998) and with tracer experiments (Anderson et al., 1997a). There is effectively no discharge from the CB1 catchment during prolonged dry periods; saturation within the colluvium disappears a few days after rain stops. During rainfall events, water moves predominantly as vertical flow through the vadose zone in the colluvium (Torres, 1997), at a rate controlled by the rainfall rate and the volumetric water content of the colluvium (Anderson et al., 1997a). Saturation develops in a thin discontinuous layer at the base of the colluvium and does not reach the soil surface anywhere in the catchment (Montgomery, 1991; Montgomery et al., 1997). Over most of the catchment, water percolates into the weathered and fractured bedrock, where it develops a perched water table and flows laterally towards the valley axis and channel head. Measured head gradients indicate that water exfiltrates out of the bedrock and into the narrow zone of saturated colluvium near the channel head during natural storms, and that this behaviour occurred during the steady discharge period of experiment 3 (Montgomery et al., 1997). We labelled this near-channel zone of saturated colluvium, which expands and contracts in response to rainfall events, the subsurface variable source area (Anderson et al., 1997a).

There are flow path differences between high flow and low flow conditions. Deep water flow exfiltrating from the bedrock is the dominant source of discharge during periods of low flow. Direct percolation through the soil and out of the catchment without bedrock interaction is possible only during periods of high flow when saturation develops at the base of the colluvium. Our tracer experiments and hydrometric data suggest that the 'soil only' path contributed about 7\% of the runoff during our sprinkler experiments (Anderson et al., 1997a).

\section{Flowpaths and soil water chemistry interpretation}

Water percolated vertically through the soil and into the bedrock everywhere in the catchment during sprinkling experiment 3 , except in the saturated area near the upper weir. Because the dominant flow direction is down, the lysimeters within any particular nest (delineated on Figure 1) may be treated as a one-dimensional vertical array. Under steady flow conditions, the resulting profile shows the evolution of water as it percolates through the colluvium.

The weirs and the lysimeters located in the saturated zone near the upper weir $(1-1 \mathrm{C}, 0-2 \mathrm{z}, 0-1$, and 0 1C) receive waters both from percolation through the soil, and from exfiltration from bedrock. Because they receive water from several sources, these lysimeters must be interpreted separately.

\section{Colluvium water balance}

Interpretation of the soil water chemistry in the lysimeters will be enhanced by knowing the proportions of old (pre-experiment) water and new (sprinkler-applied) water in the colluvium. In this section, we therefore constrain the water balance in the colluvium throughout experiment 3, paying particular attention to the distribution of old and new water. Analysis of water movement is straightforward for the steady-discharge period of experiment 3, when the plug flow model applies (Anderson et al., 1997a). However, water movement during transient flow conditions is more complicated and was not constrained by artificial tracer studies. For transient flow conditions we use water balance and chloride as a natural tracer to put limits on the movement of new water into the subsurface.

For the water balance analysis, we will use rainfall and runoff measurements, as well as data from Torres (1997) on soil water content at the start and during the steady flow period of experiment 3 . Dry antecedent conditions prior to the experiment led to low water contents in the vadose zone at the outset. We estimate initial water storage of $133 \mathrm{~mm}$ in the colluvium based on measured water content and soil depths. A substantial proportion of the effective rain $I_{\mathrm{e}}$ (rainfall minus evaporation) before steady flow conditions were reached went into soil water storage (Figure 4). The monotonic rise in discharge ceased with the 30 May 00:35 measurement; this time is therefore considered the beginning of steady flow conditions for this analysis. The change in the catchment-wide water storage $\Delta \mathrm{S}$ is

$$
\Delta S=\sum I_{\mathrm{e}}-\sum Q_{\mathrm{total}}
$$




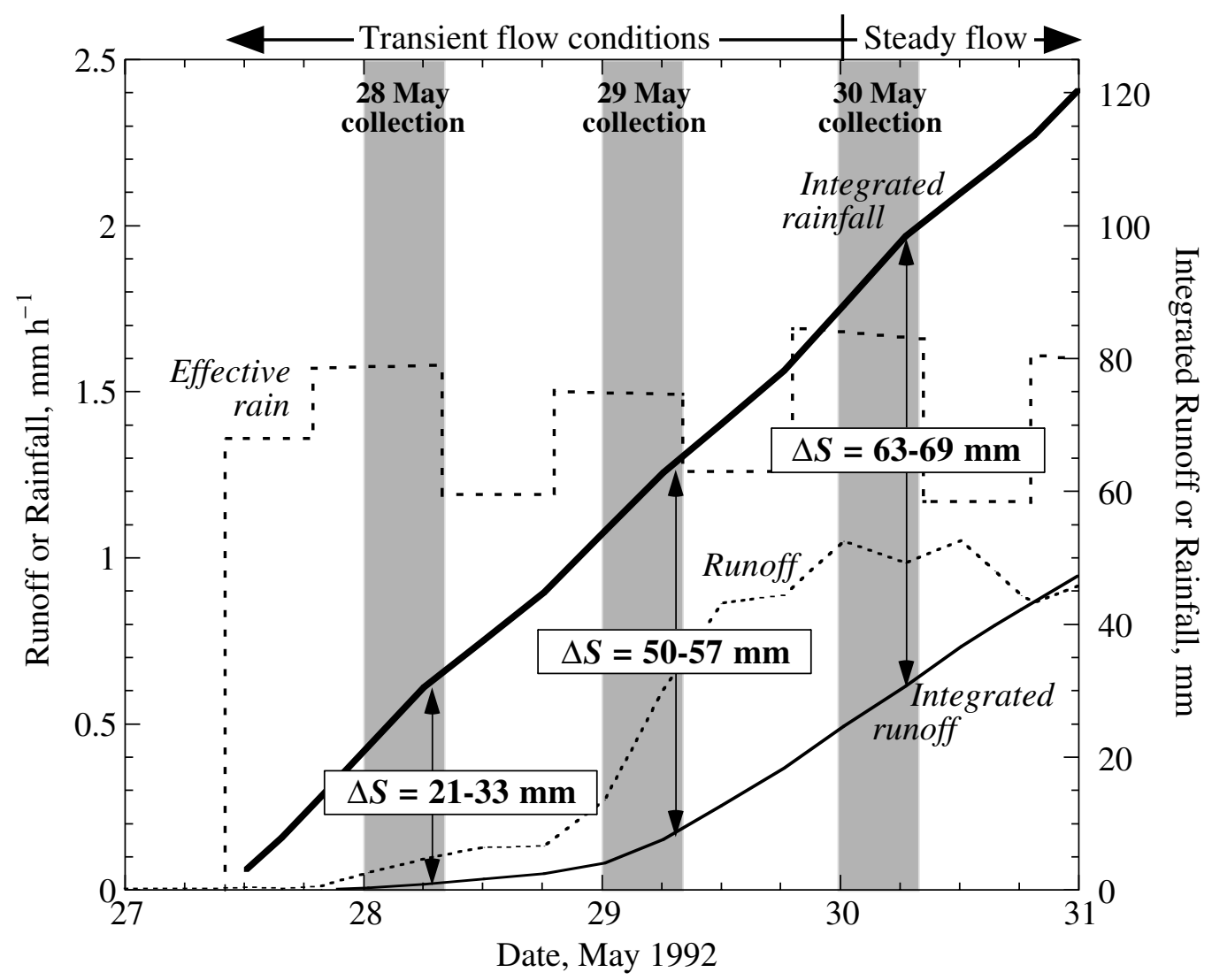

Figure 4. Calculation of changes of soil water storage $\Delta S$ from the original fully drained condition during the wetting-up portion of sprinkling experiment 3. Dotted curves show rainfall and runoff rates (runoff from the upper and lower weirs have been combined to give the total runoff from the catchment); steady discharge began after the 00:35 discharge measurements on 30 May. Solid curves show the integrated rainfall and runoff from the start of the experiment at 10:00 on 27 May. The change in soil water storage is given by the difference between these curves. Values of $\Delta S$ are given in boxes for three lysimeter sample collection times (shaded)

where $Q_{\text {total }}$ is the combined discharge from the upper and lower weirs, and the summations of rainfall and runoff are from the time the sprinklers were turned on: 27 May, 10:00. The change in storage is distributed across storage in the soil $\Delta S_{\text {soil }}$, and storage in the weathered bedrock $\Delta S_{\text {rock }}$, and includes any deep leakage from the catchment not measured at the weirs $Q_{\text {deep }}$ :

$$
\Delta S=\Delta S_{\text {soil }}+\Delta S_{\text {rock }}+Q_{\text {deep }}
$$

During the wetting up period, we assume that all of the change in storage can be assigned to increases in the soil water content, and that neither does storage in the weathered bedrock change, nor is deep leakage significant, so that Equation (2) simplifies to $\Delta S=\Delta S_{\text {soil }}$. This assumption is not strictly correct. Bedrock piezometers responded during the wetting up period, but since the fracture porosity of the bedrock is unknown, the $\Delta S_{\text {rock }}$ term is unconstrained. Given this simplification, calculated soil water storage for lysimeter sample collection times during the wetting up period are shown in Table I.

The total soil water content in $S_{\mathrm{t}}(\mathrm{mm})$ can be estimated by assigning all of the change in storage to the soil and combining it with the antecedent water content $S_{0}$,

$$
S_{\mathrm{t}}=\Delta S+S_{0}
$$


Table I. Soil water balance for lysimeter sample collection times during the transient wetting-up phase of sprinkling experiment 3

\begin{tabular}{|c|c|c|c|c|c|c|c|}
\hline Date/time & $\begin{array}{l}\text { Effective rain } \\
\sum I_{\mathrm{e}}(\mathrm{mm})\end{array}$ & $\begin{array}{l}\text { Combined runoff } \\
\sum Q_{\text {total }}(\mathrm{mm})\end{array}$ & $\begin{array}{c}\Delta S \\
(\mathrm{~mm})\end{array}$ & $\begin{array}{c}S_{0} \\
(\mathrm{~mm})\end{array}$ & $\begin{array}{c}S_{\mathrm{t}} \\
(\mathrm{mm})\end{array}$ & $\theta_{\mathrm{v}}$ & $\begin{array}{c}\text { Fraction new water } \\
\sum \sum I_{\mathrm{e}} / S_{\mathrm{t}}\end{array}$ \\
\hline \multicolumn{8}{|l|}{$28 / 5 / 92$} \\
\hline 00:39 & $21 \cdot 6$ & $0 \cdot 3$ & 21 & 133 & 154 & $0 \cdot 22$ & $0 \cdot 14$ \\
\hline 08:10 & $33 \cdot 6$ & $1 \cdot 0$ & 33 & 133 & 166 & $0 \cdot 24$ & $0 \cdot 20$ \\
\hline \multicolumn{8}{|l|}{ 29/5/92 } \\
\hline $00: 24$ & $54 \cdot 0$ & $4 \cdot 1$ & 50 & 133 & 183 & $0 \cdot 26$ & $0 \cdot 30$ \\
\hline 08:07 & $65 \cdot 8$ & $9 \cdot 0$ & 57 & 133 & 190 & $0 \cdot 27$ & $0 \cdot 35$ \\
\hline \multicolumn{8}{|l|}{$30 / 5 / 92$} \\
\hline $00: 35$ & $88 \cdot 0$ & $24 \cdot 6$ & 63 & 133 & 196 & 0.28 & 0.45 \\
\hline $08: 45$ & $101 \cdot 7$ & $32 \cdot 7$ & 69 & 133 & 202 & 0.29 & 0.50 \\
\hline
\end{tabular}

Effective rain is the total rainfall less evaporation from the beginning of the sprinkling experiment. Evaporation data from TW Giambelluca Personal Communication (1993).

Combined runoff is from the upper and lower weirs, integrated from beginning of experiment.

$\Delta S$ is the change in storage: $\sum I_{\mathrm{e}}-\sum Q_{\text {total }} . S_{0}$ is the initial soil moisture content. $S_{\mathrm{t}}=\Delta S+S_{0} . \theta_{\mathrm{v}}$ is the average volumetric soil water content, assuming soil thickness of $0.7 \mathrm{~m}$ and uniform moisture distribution.

The average volumetric soil moisture content $\theta_{\mathrm{v}}$ can then be computed for the wetting up period (Table I):

$$
\theta_{\mathrm{v}}=\frac{S_{\mathrm{t}}}{h}
$$

where $h$ is the average soil thickness. The volumetric soil water content reached at the start of steady flow conditions calculated in this manner is $0.29 \mathrm{~m}^{3} \mathrm{~m}^{-3}$, nearly half the measured porosity of 0.7 of the soil, and close to the measured steady-state average soil water content of $0.32 \pm 0.05 \mathrm{~m}^{3} \mathrm{~m}^{-3}$ (Torres, 1997: 116). The close agreement between measured and calculated soil water content justifies our assumption of no change in bedrock water storage, although the amount of storage and changes in storage in the bedrock remains an important open question. Dividing the total effective rainfall by the amount of water in the soil $S_{\mathrm{t}}$ yields a measure of the fraction of new water in the soil:

$$
\% \text { new water }=\frac{\sum I_{\mathrm{e}}}{S_{\mathrm{t}}}
$$

For the lysimeter samples collected at the start of the steady flow conditions on 30 May, new water comprised $45-50 \%$ of the total water. Since this estimate is catchment-averaged, it does not indicate the distribution of new water with depth in the profile.

One way to trace old versus new water during the wetting up period of the experiment is with the chloride concentration. The demineralized water applied with the sprinklers had an average chloride concentration of $0.15 \pm 0.09 \mathrm{ppm}$, much lower than the average soil water chloride concentration of $4.96 \pm 3.96 \mathrm{ppm}$ in the first sample collection of the experiment 3, on 28 May (Figure 5). From Equation (5), new rain water accounted for only $14-20 \%$ of the soil water in the 28 May lysimeter samples (Table I), and therefore the high chloride concentrations that day largely reflect old water compositions. This initial profile, characterized by high chloride concentrations in the shallow $(<0.5 \mathrm{~m})$ soil, most likely results from evaporative concentration of soil water. The concentration of chloride declined throughout the soil profiles after 28 May (Figure 5). The lack of a coherent downward displacement of high chloride concentration water by low concentrations implies that rainwater mixed with the old water throughout the soil during transient flow conditions, rather than simply displacing it in a plug flow manner. This leads to the conclusion that new water reached as deep as $0.5 \mathrm{~m}$ in the first 3 days of sprinkling, a result consistent with the time-domain reflectometry and pressure 


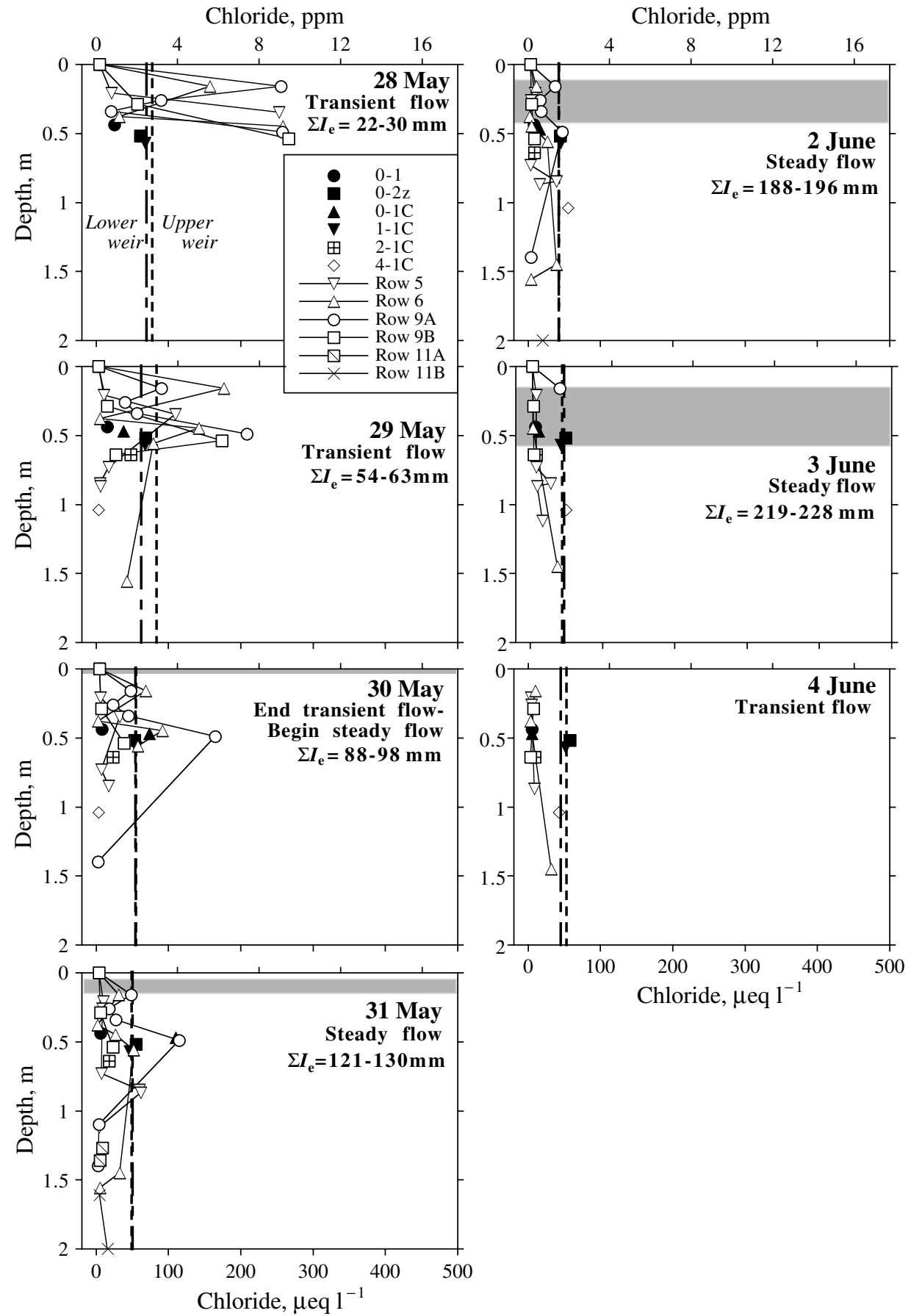

Figure 5. Chloride concentration as a function of depth during sprinkling experiment 3. Rain water concentrations are the top point in each profile. Lines connect lysimeters within a nest. Filled symbols indicate lysimeters located in saturated colluvium near the upper weir. The vertical lines show the chloride concentrations of the two weirs at approximately 06:00 each day; the lysimeter samples were obtained with suction applied from about 00:00-09:00 each day. Horizontal bands show the calculated depth to which rain that fell from 00:00 to 08:00 on 30 May (the onset of steady flow conditions) would reach due to plug flow (see text). A vacuum pump failure on 1 June resulted in low sample recovery on that day, so it is not included in the figure 
head measurements of Torres (1997). The few water samples obtained from depths greater than $0.5 \mathrm{~m}$ during the transient flow conditions had low chloride concentrations, and are therefore difficult to distinguish from new water.

The simple water balance calculation shown in Figure 4 documents continued divergence of the integrated rainfall and integrated runoff after quasi-steady discharge began at the weirs, implying increasing water storage in the catchment during the period of quasi-steady discharge. This suggests that the final two right-hand terms in Equation (2) are non-zero after the wetting up period. The soil moisture measurements made by Torres (1997) were quasi-steady in the vadose zone during the period of quasi-steady discharge, and he attributed the continued divergence in rainfall and runoff to leakage to the fractured bedrock underlying the colluvium. The quasi-steady discharge period will therefore be treated as having constant soil moisture and steady flow conditions. This is justified by the steady head gradients during the period of steady discharge (Torres, 1997).

The total effective rainfall $\sum I_{\mathrm{e}}$ exceeded the old water content of the colluvium $\mathrm{S}_{0}$ of $133 \mathrm{~mm}$ by 1 June 16:00. If plug flow characterizes both transient and steady water flow through the catchment, then all of the lysimeter samples collected on and after 2 June should reflect new water. From the chloride data it appears more likely, however, that the transient water flow conditions promoted mixing of old and new water to at least a depth of $0.5 \mathrm{~m}$. Plug flow probably did not begin until the water content in the soil rose to the point that the head gradient and conductivity were sufficient to transmit water at the rate of the rainfall, i.e. until steady flow conditions began. Thereafter, new water displaced the mixed old and new water down through the soil. The downward progress of the boundary between new water and mixed old and new water after steady flow began is shown with shaded bands on the panels in Figure 5. The bands show the calculated depths reached by rain that fell during the first $8 \mathrm{~h}$ of steady flow conditions (i.e. the time during which the lysimeter samples were collected on 30 May). Under steady flow conditions, the movement of water can be modelled as plug flow (Anderson et al., 1997a), the flow rate $q_{\mathrm{w}}$ controlled by the rainfall rate $I_{\mathrm{e}}$ and the volumetric water content of the colluvium $\theta_{\mathrm{v}}$ :

$$
q_{\mathrm{w}}=\frac{I_{\mathrm{e}}}{\theta_{\mathrm{v}}}
$$

The depths reached by new water shown in Figure 5 are calculated from equation (6) for a range of effective rainfall rates $\left(1.38 \pm 0.77 \mathrm{~mm} \mathrm{~h}^{-1}\right)$ and moisture contents $(0.4-0.6)$. These calculations, which are consistent with the deuterium tracer study, show that rain that fell during steady flow conditions reached a maximum of $0.5 \mathrm{~m}$ depth by the 3 June sprinkler shut down. During the steady flow conditions from 31 May through to 3 June, samples in unsaturated colluvium (open symbols) that plot in and above the horizontal bands on Figure 5 are considered new water, whereas samples below these bands are likely to be mixtures of new and old water. The proportion of new water in the mixed zone is constrained by the ratios of rainwater to total soil water shown in the last column of Table I.

\section{RESULTS AND DISCUSSION}

\section{Precipitation chemistry}

The chemistry of precipitation samples collected during experiment 3 are compared in Table II with eight natural rain samples collected at the CB1 catchment. The total dissolved solids (TDS) of the demineralized sprinkler water from experiment 3 averaged $8.03 \pm 6.48 \mathrm{ppm}$, considerably lower than the $c a 50 \mathrm{ppm}$ TDS in the untreated water used in our earlier experiments (Anderson et al., 1997b). Silicon comprised nearly $90 \%$ of the solute in the treated water, and peaked in concentration at $23.3 \mathrm{ppm}$ on 29 May. The particulate filter in the demineralizing system was thoroughly backflushed for the first time after this, and the silicon concentrations subsequently declined. Silicon concentrations increased again towards the end of the experiment, when the particulate filter clogging was apparently more than could be relieved by backflushing. 
Table II. Average chemistry of sprinkler water during experiment 3 compared with natural rains sampled at the CB1 catchment. All concentrations in ppm. bd: below detection

\begin{tabular}{|c|c|c|c|c|}
\hline \multirow[t]{2}{*}{ Solute } & \multicolumn{2}{|c|}{ Sprinkling experiment } & \multicolumn{2}{|c|}{ Natural storms } \\
\hline & $x \pm \sigma$ & $n$ & $x \pm \sigma$ & $n$ \\
\hline $\mathrm{pH}$ & $5 \cdot 38 \pm 0 \cdot 28$ & 14 & $5.53 \pm 0.19$ & 8 \\
\hline Alkalinity & $0 \cdot 26 \pm 0.41$ & 14 & $0.41 \pm 0.22$ & 5 \\
\hline $\mathrm{Cl}$ & $0 \cdot 16 \pm 0.09$ & 14 & $0.46 \pm 0.32$ & 7 \\
\hline $\mathrm{NO}_{3}$ & $0.03 \pm 0.04$ & 14 & $0.13 \pm 0.15$ & 8 \\
\hline $\mathrm{SO}_{4}$ & $0.08 \pm 0.05$ & 14 & $0.27 \pm 0.35$ & 8 \\
\hline $\mathrm{Na}$ & $0.07 \pm 0.07$ & 11 & $0.24 \pm 0.17$ & 6 \\
\hline $\mathrm{Ca}$ & $0.05 \pm 0.06$ & 11 & $0.05 \pm 0.05$ & 8 \\
\hline $\mathrm{Mg}$ & $0.03 \pm 0.02$ & 9 & $0.09 \pm 0.14$ & 7 \\
\hline K & $0 \cdot 16 \pm 0 \cdot 11$ & 4 & $0.03 \pm 0.05$ & 4 \\
\hline $\mathrm{Al}$ & $0.02 \pm 0.02$ & 10 & $0.01 \pm 0.00$ & 5 \\
\hline $\mathrm{Fe}$ & $0 \cdot 29 \pm 0.06$ & 14 & $0.01 \pm 0.01$ & 5 \\
\hline $\mathrm{Si}$ & $7 \cdot 56 \pm 6 \cdot 61$ & 13 & bd & \\
\hline TDS & $8.03 \pm 6.48$ & 14 & $2.62 \pm 3.72$ & 8 \\
\hline TDS w/o Si & $1.01 \pm 0.79$ & 14 & & \\
\hline
\end{tabular}

The average solute concentration in the treated sprinkler water, exclusive of silicon, was $1.01 \pm 0.79 \mathrm{ppm}$, iron and chloride being the two largest components. The $\mathrm{pH}$ of the treated water ranged from 4.80-6.07, averaging $5 \cdot 38 \pm 0 \cdot 28$, essentially in equilibrium with atmospheric $\mathrm{CO}_{2}$. In natural rain samples, TDS concentrations averaged $2.6 \pm 3.7 \mathrm{ppm}$, and $\mathrm{pH}$ values averaged $5.53 \pm 0 \cdot 19$. The large standard deviation in TDS reflects one sample with high seasalts; if this sample is omitted, the average TDS concentration falls to $1.3 \pm 0.6 \mathrm{ppm}$. Except for the problem of elevated silicon concentrations, the demineralized water used in experiment 3 compares well in $\mathrm{pH}$ and total dissolved solids with natural rains that are low in seasalts.

\section{Runoff and soil water: TDS}

After an initial period of high variability with depth, the TDS in soil water profiles fell within a narrow range of 10-20 ppm, which was significantly lower than the TDS concentration in the runoff (Figure 6). Most of the initial variability can be attributed to chloride. TDS in the precipitation, shown at the top of each profile, reached as high as $23 \mathrm{ppm}$ during the experiment, almost entirely due to the presence of silica.

Total dissolved solids concentrations comparable to the concentrations in the weirs were observed consistently in samplers $1-1 \mathrm{C}$ and $0-2 \mathrm{z}$, located in the saturated layer at the base of the colluvium near the upper weir (Figure 1). The other two samplers within the saturated layer near the weir, 0-1 and 0-1C, had TDS concentrations in the range observed in the vadose zone samplers.

\section{Solute sources in the catchment}

The total dissolved solids in the runoff at the weirs was more than twice that of the soil water (Figure 6). Total dissolved solids in the soil are greatest in the few places where our tracer experiments (Anderson et al., 1997a) and piezometric observations (Montgomery et al., 1997) show that water exfiltrates from the bedrock. Clearly, some of the solutes in the runoff are derived from weathering in the bedrock. But how important is weathering in the rock compared with weathering taking place within the soil in the total chemical denudation from the catchment?

A solute mass balance can be easily constructed for experiment 3 by taking advantage of the steady water fluxes within the catchment during the period of steady discharge. For the purposes of the solute mass balance, 

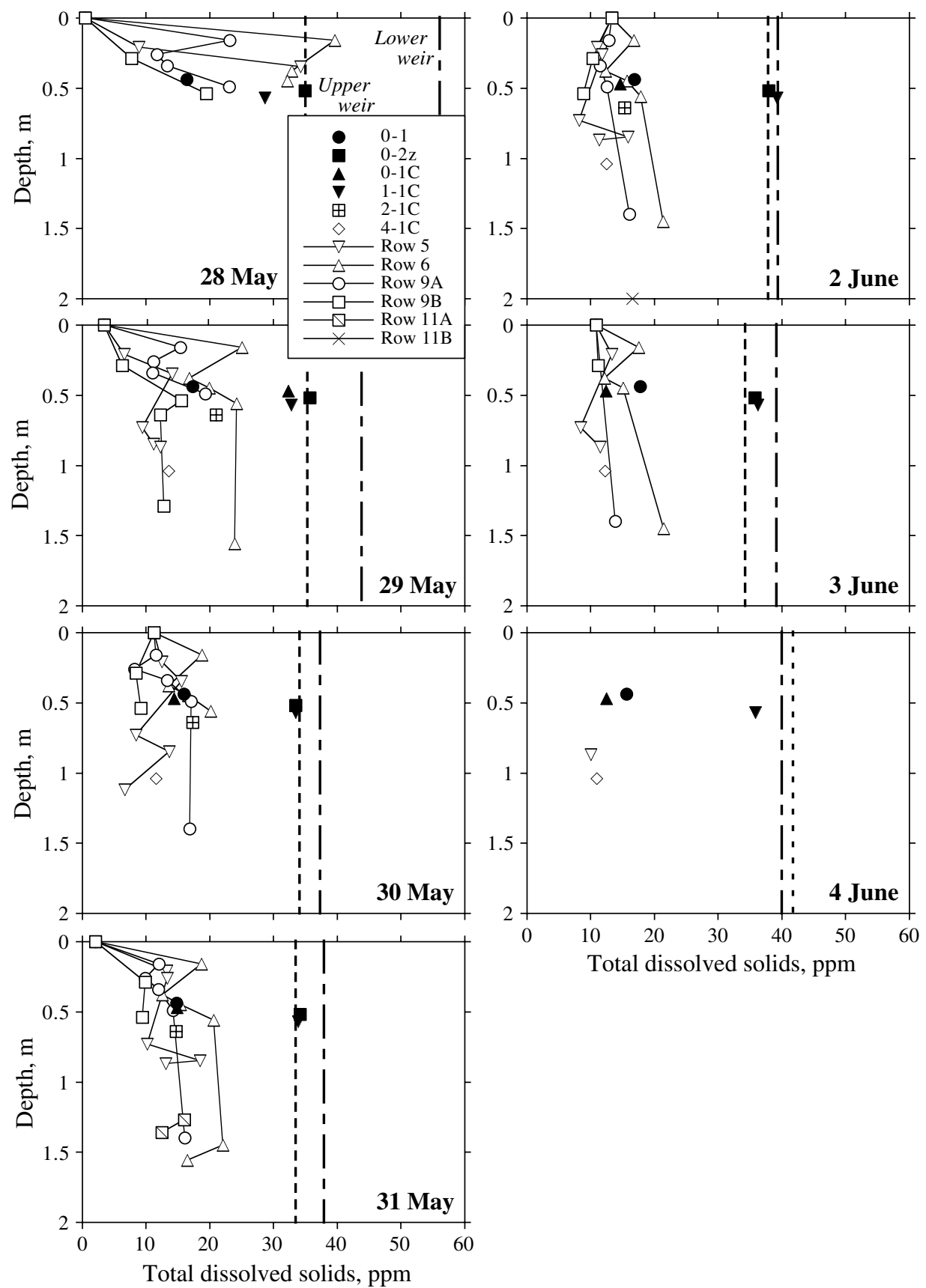

Figure 6. TDS (ppm) in the lysimeters and runoff during sprinkling experiment 3. Lines connect lysimeters within a nest. Filled symbols indicate lysimeters located in saturated colluvium near the upper weir. The vertical lines show the TDS concentrations of the two weirs

the subsurface of the catchment is divided into two layers, soil and bedrock. The soil is taken as the entire thickness of colluvium, and bedrock includes all hydrologically active weathered rock layers. The runoff from the catchment $Q_{\text {total }}$ consists of a mixture of water that has travelled only through the soil to the weirs $Q_{\mathrm{S}}$, and of water that has exfiltrated from the bedrock $Q_{\mathrm{R}}$. During the period of steady discharge, the runoff is 
equal to the effective rainfall rate $I_{\mathrm{e}}$ :

$$
Q_{\text {total }}=Q_{\mathrm{S}}+Q_{\mathrm{R}}=I_{\mathrm{e}}
$$

As $Q_{\text {total }}$ is the combined runoff from both weirs, Equation (7) implies that there is no deep leakage from the catchment. The tracer experiments and the area of the subsurface variable source area near the channel head (Anderson et al., 1997a; Montgomery et al., 1997) suggest that, at steady state in experiment 3, $Q_{\mathrm{S}}$ was $7 \%$ of the total runoff from the catchment during the period of steady discharge, and therefore that $93 \%$ of the runoff passed through the bedrock $\left(Q_{\mathrm{R}}\right)$.

The net solute flux out of the catchment is the difference between the output flux $Q_{\text {total }} C_{\text {total }}$, and the input flux $Q_{\text {total }} C_{\mathrm{P}}$, and may therefore be written:

$$
Q_{\text {total }}\left(C_{\text {total }}-C_{\mathrm{P}}\right)
$$

where $C_{\text {total }}$ is the concentration of dissolved species derived from mineral weathering (all measured species other than bicarbonate alkalinity, and nitrate) in the combined runoff and $C_{\mathrm{P}}$ is the concentration of dissolved species in the precipitation. We assume that the alkalinity is produced from dissolved $\mathrm{CO}_{2}$ through its reaction with silicate minerals, although a portion probably comes from carbonate dissolution in the bedrock. Because all water passes through the soil as it moves through the catchment, and the effective rainfall rate is equal to the runoff at steady flow, the net solute flux from the soil is:

$$
Q_{\text {total }}\left(C_{\mathrm{S}}-C_{\mathrm{P}}\right)
$$

where $C_{\mathrm{S}}$ is the average concentration of weathering-derived solutes in the soil water. Similarly, the net solute flux from the bedrock is:

$$
Q_{\mathrm{R}}\left(C_{\mathrm{R}}-C_{\mathrm{S}}\right)
$$

Steady-state flow conditions imply that the water flux into the rock is equal to the water flux out of the rock $Q_{\mathrm{R}} \cdot C_{\mathrm{R}}$ is the average concentration of weathering-derived solutes in the water exfiltrating the bedrock. Equations (8)-(10) can be combined to yield a statement of the partitioning of the solute flux from the catchment under conditions of steady discharge:

$$
Q_{\text {total }}\left(C_{\text {total }}-C_{\mathrm{P}}\right)=Q_{\text {total }}\left(C_{\mathrm{S}}-C_{\mathrm{P}}\right)+Q_{\mathrm{R}}\left(C_{\mathrm{R}}-C_{\mathrm{S}}\right)
$$

The first term on the right-hand side gives the solutes derived from weathering in the soil, and the second term gives the solutes derived from weathering in the rock.

All of the quantities in Equation (11) are reasonably well measured, other than the solute concentration of water emerging from the bedrock $C_{\mathrm{R}}$. The concentration of the weathering-derived species in the combined runoff, calculated from the discharge and concentrations in the upper and lower weirs, remained relatively steady during the steady discharge portion of the sprinkling experiment. Soil water concentrations of total weathering-derived solutes were fairly uniform in space and time during the steady-state discharge period. Average values will therefore be used to characterize $C_{\text {total }}$ and $C_{\mathrm{S}}$ for the steady flow conditions. As no direct measurements were made of solute concentrations in the water exfiltrating the bedrock, the bedrock-derived portion of the solute flux must be determined by difference.

Figure $7 \mathrm{a}$ illustrates the temporal and spatial uniformity of the soil water weathering-derived solute concentrations, which average $11.0 \pm 3.0 \mathrm{ppm}(n=82)$, and Figure $7 \mathrm{~b}$ shows the temporal stability of the concentrations in the runoff, which average $20.4 \pm 0.6 \mathrm{ppm}(n=7)$. The average concentration of solutes other than silica in the rain water $\left(C_{\mathrm{P}}\right)$ is $0.9 \pm 0.7 \mathrm{ppm}(n=12)$. The omission of the high silica concentrations from the solute input is justified given the lysimeter evidence that high silica concentrations did not travel all the way through the soil column (see Figure 8).

The net weathering-derived solute flux from the catchment (the left-hand side of Equation (11)) during the period of steady discharge was $20.8 \pm 1.1 \mathrm{mg} \mathrm{m}^{-2} \mathrm{~h}^{-1}$. The net solute flux from the soil was $10.7 \pm$ 

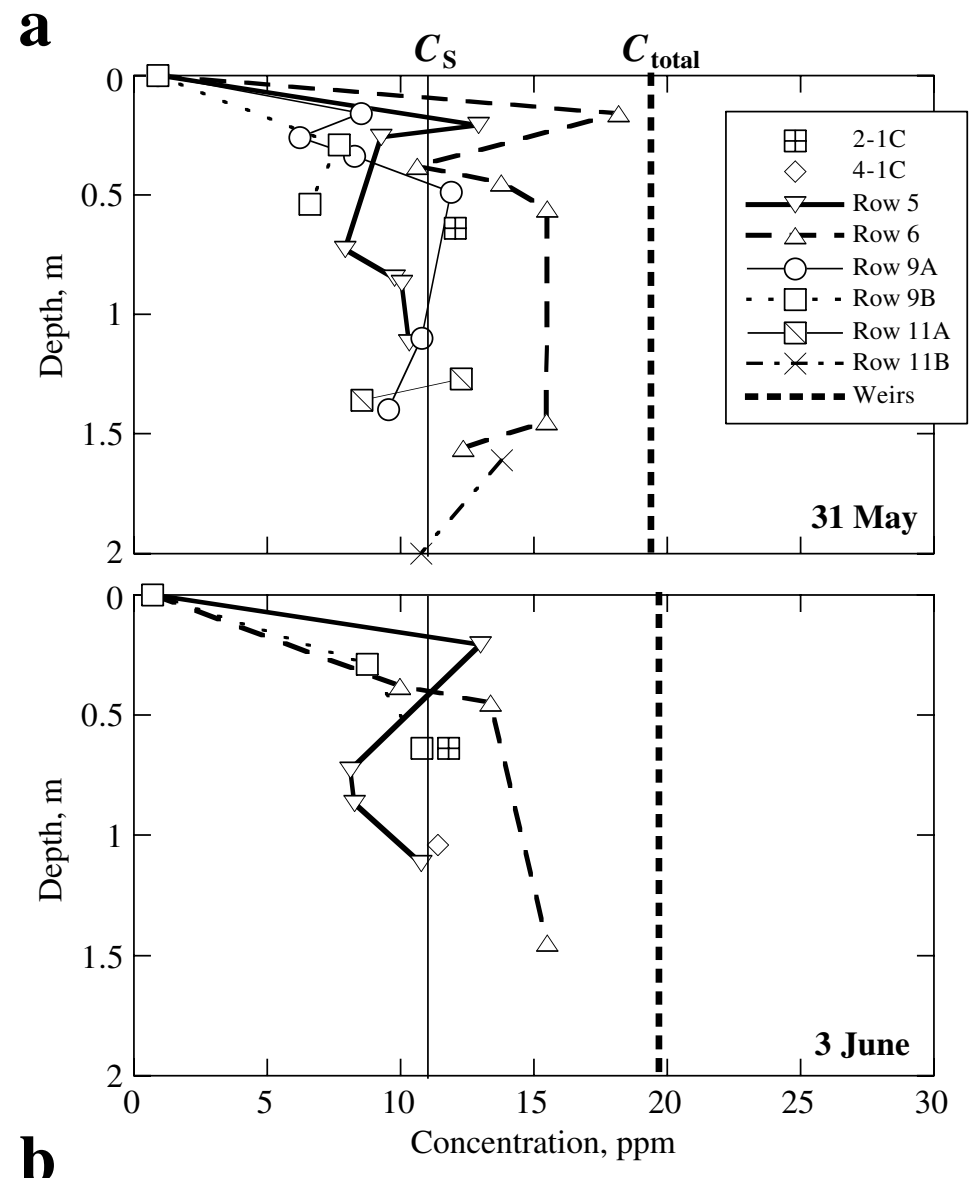

b

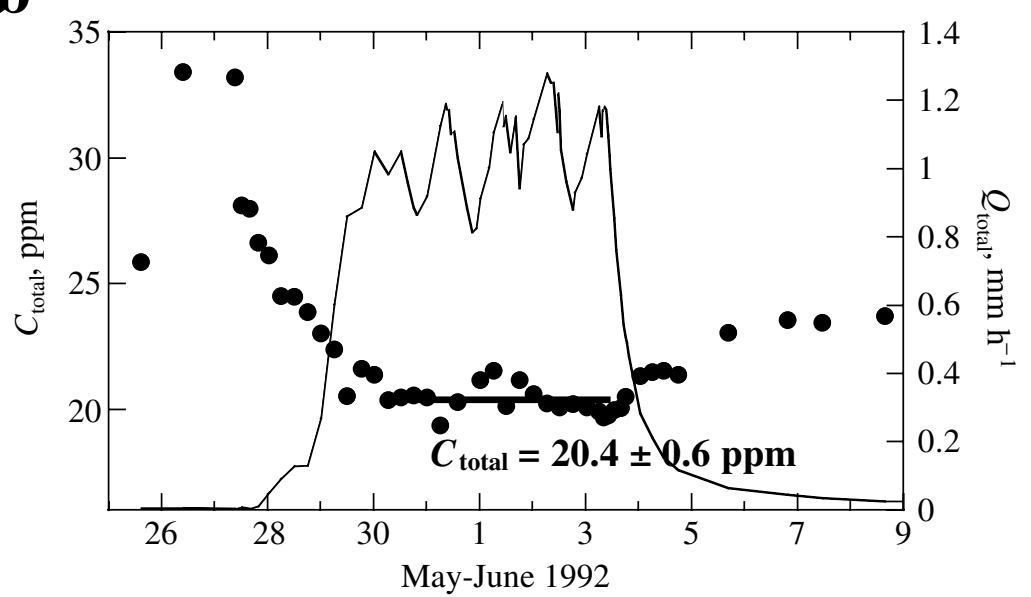

Figure 7. Weathering-derived solute concentrations in soil water and runoff during steady flow conditions of experiment 3. (a) Profiles of weathering-derived solute concentrations in the soils on 31 May, early in the steady-discharge period, and on 3 June, at the end of the steady discharge period. Vertical lines show the average $C_{\mathrm{S}}$ value of $11 \mathrm{ppm}$, and $C_{\text {total }}$, the concentration in the combined discharge from the upper and lower weirs. (b) Weathering-derived solute concentration in the combined discharge from the weirs through the sprinkling experiment. Horizontal bar shows the average value of $C_{\text {total }}$. Combined hydrograph from the upper and lower weirs shown for reference 
$3 \cdot 1 \mathrm{mg} \mathrm{m}^{-2} \mathrm{~h}^{-1}$; therefore, by difference, the net solute flux from the bedrock was $10 \cdot 1 \pm 3 \cdot 3 \mathrm{mg} \mathrm{m}^{-2} \mathrm{~h}^{-1}$. This essentially equal partitioning of the weathering-derived solutes between the bedrock and the soil contrasts sharply with the partitioning of the sources of water in the runoff. Whereas $93 \%$ of the runoff travels through the bedrock, only half of the solutes come from that part of the flowpath. The solute partitioning in the runoff implies that chemical denudation is evenly split between soil and bedrock sources in the CB1 catchment, as was inferred by Reneau and Dietrich (1991) for nearby catchments in the Oregon Coast Range.

Equation (11) can also be rearranged to solve for the unmeasured concentration of water emerging from the bedrock:

$$
C_{\mathrm{R}}=\left(Q_{\text {total }} / Q_{\mathrm{R}}\right)\left(C_{\text {total }}-C_{\mathrm{S}}\right)+C_{\mathrm{S}}
$$

The calculated value of $C_{\mathrm{R}}$ is $21.1 \pm 4.3 \mathrm{ppm}$, using the experimentally determined value of 0.93 for the proportion of the water flux from the bedrock, $Q_{\mathrm{R}} / Q_{\text {total }}$. This concentration is lower by 3-9 ppm (10-30\%) than the solute concentration in the weirs at low flow, before and after the sprinkling experiment (Figure 7), when all of the runoff is generated from bedrock exfiltration.

The discrepancy between the water and solute partitioning suggests either that weathering processes are more rapid in the soil, or that much of the water flow through the bedrock is too fast for solute acquisition due to weathering to occur. Flow through the bedrock is probably largely accommodated through open fractures, which would have high flow velocities when filled. Our tracer injections (Anderson et al., 1997a) show that water velocities in parts of the bedrock are very high (up to $4 \times 10^{-3} \mathrm{~m} \mathrm{~s}^{-1}$ ) during the steady flow conditions of experiment 3. The lower concentration of water emerging from the bedrock at high discharge (calculated with Equation (12)) compared with the runoff at low discharge is consistent with flushing of fractures during more extensive saturation and increased hydraulic head gradients at high flow. This is consistent with the idea that contact time is important in setting the concentration of water emerging from the bedrock.

Two competing effects may be at work here. Water in the bedrock, having already passed through the soil, will have solute concentrations closer to saturation with respect to weathering phases than soil waters. The approach to saturation may lead to slower reaction rates in the bedrock. However, the bedrock has been exposed to weathering conditions for less time than has the soil. The bedrock, therefore, is likely to contain greater quantities of more soluble phases for which weathering rates are faster.

If the kinetics of weathering in the bedrock and in the soil are the same, or nearly the same, then the even split between solute flux from the soil and bedrock suggests that the mean residence times of water in the soil and in the weathered rock are equivalent. This implies that rapid flow documented with tracer injections is applicable to restricted areas in the bedrock, and that flow is very slow in other areas, such as near the margins where upslope contributing area is small and water fluxes are low. The total solute flux out of the bedrock reflects the mixture of water that has had a very long residence time in the rock, and undergone considerable chemical evolution, and of water that has flushed through quickly. As a consequence of the largely vertical flow paths through the soil, the spectrum of flow path lengths and contact times is narrower in the soil, allowing its characterization with a single solute concentration.

The volume of the weathered rock layers underlying the CB1 catchment exceeds the volume of soil in the catchment by three- or four-fold (see Figure 1, for example). The weathered rock layers thin to about $3 \mathrm{~m}$ near the channel head, and probably are about this thickness on the interfluves bordering the catchment. This contrasts with the average colluvium thickness of $0.7 \mathrm{~m}$. That the weathered-derived solute flux from the small body of colluvium equals the solute flux from the larger volume of hydrologically active weathered bedrock implies that the intensity of chemical weathering is much greater in the soil.

\section{Chemical denudation rate}

The net solute flux from the catchment of $20.8 \mathrm{mg} \mathrm{m}^{-2} \mathrm{~h}^{-1}$ during steady discharge conditions is equivalent to $182 \mathrm{t} \mathrm{km}^{-2}$ year $^{-1}$, or a bedrock lowering rate of $79 \mu \mathrm{m}$ year $^{-1}$, using the measured bedrock density of $2.3 \times 10^{3} \mathrm{~kg} \mathrm{~m}^{-3}$. That denudation rate is not sustained, however, because the steady discharge rate of the 
experiment is not maintained over the course of a year. The chemical denudation rate can be estimated, however, from the average solute concentration under conditions of steady flow and the annual discharge rate. The solute concentration during steady flow is a reasonable value to use for this calculation: solute concentrations do not vary by more than $20 \%$ per order of magnitude discharge variation, and the steady state discharge of $1.06 \mathrm{~mm} \mathrm{~h}^{-1}$ falls in the middle of the range of expected discharges on a logarithmic scale. Therefore, the experimental steady discharge solute concentration of $20 \mathrm{ppm}$ with $20 \%$ error bars $( \pm 4 \mathrm{ppm})$ covers the range of expected variations in solute concentrations. The average discharge, based on 3 years of measured rainfall and runoff from the CB1 catchment and an analysis of nearby USGS gauged streams and rain gauges, is $1.6 \pm 0.4 \mathrm{~m} \mathrm{year}^{-1}$ (Anderson, 1995). These yield a chemical denudation rate from the CB1 catchment of $32 \pm 10 \mathrm{t} \mathrm{km}^{-2}$ year $^{-1}$, or a bedrock lowering rate of $14 \pm 4 \mu \mathrm{m} \mathrm{year}{ }^{-1}$.

The chemical denudation rate of the CB1 catchment is similar to the total chemical denudation rate of 25-30 t km${ }^{-2}$ year $^{-1}$ (bedrock lowering of $11 \mu \mathrm{mear}^{-1}$ ) calculated by Dethier (1986) from solute loads in the nearby West Millicoma and Siuslaw rivers, which also drain basins underlain by Eocene greywackes. The similarity in chemical denudation rates despite differences in scale (the West Millicoma is $122 \mathrm{~km}^{2}$, whereas the Siuslaw is $1523 \mathrm{~km}^{2}$ ) shows that understanding weathering on the small scale of the CB1 catchment is relevant to interpreting continental-scale weathering. As one might infer from the small amount of deep leakage from the CB1 catchment and the highly dissected nature of the Oregon Coast Range, very little additional solute acquisition takes place in larger catchments, because the water and solute flux from groundwater circulation at a scale more extensive than the CB1 catchment are not large.

\section{Soil water chemistry}

Profiles of soil water solute concentrations and concentrations in the runoff at the weirs are shown for 1 day representative of the steady discharge period in Figure 8. Unlike the TDS, most species display consistent trends with depth in the vadose zone.

Most of the soil water samples displayed a significant deficit of negative charge (Figure 8), which we attribute to unmeasured 'organic' anions in solution, following Ugolini and Dahlgren (1987). The quotation marks around 'organic' emphasize that these species are not measured directly. The soil solutions with the largest charge deficits were slightly tea-coloured, supporting the interpretation that the charge deficit arises from organic anions. The 'organic' anion concentrations are greater in the soil than in the incoming rainwater, indicating that soluble organics are being leached from the soil organic matter.

The solution profiles show a maximum in 'organic' anion, aluminium, potassium, and iron concentrations at shallow depths. Calcium in one profile (row 6) also displays a maximum concentration at shallow depths. These vadose zone profiles display the same magnitude and pattern of solute concentrations as Spodosols in the Cascade Range (Ugolini and Dahlgren, 1987; Dahlgren and Ugolini, 1989), indicating that podzolization is occurring in these soils. Organic-acid-mediated silicate weathering causes the high aluminium, iron and cation concentrations at shallow depths. Incongruent $\mathrm{H}_{2} \mathrm{CO}_{3}$-driven weathering reactions deeper in the soil produce high $\mathrm{pH}$ and alkalinity and low iron and aluminium concentrations. There is no visible leached layer in these soils. However, the presence of abundant organic material in the litter layer at the surface, and of organic carbon throughout the soil profile (Figure 2), provides the necessary environment for the chemical processes of podzolization to occur in these soils. The colluvium in the CB1 catchment is probably mid-Holocene in age (Reneau and Dietrich, 1990, 1991). Since Spodosols can develop within a few hundred to a few thousand years (Buol et al., 1980), the lack of horizon development in the Inceptisols of the Coast Range must be attributed to a high rate of soil disturbance and mixing by bioturbation and soil creep.

The suggestion of a bulge in the chloride profile is probably a remnant of the dilution of soil water chloride that accompanied wetting up (see Figure 5). Unlike the other concentration maxima, the chloride peak did not persist through the steady flow period. The peak in silica concentration seen in Figure 8 appears to represent downward advection of the high silica rainwater from 30 May rather than a soil chemical process (Anderson, 1995). 

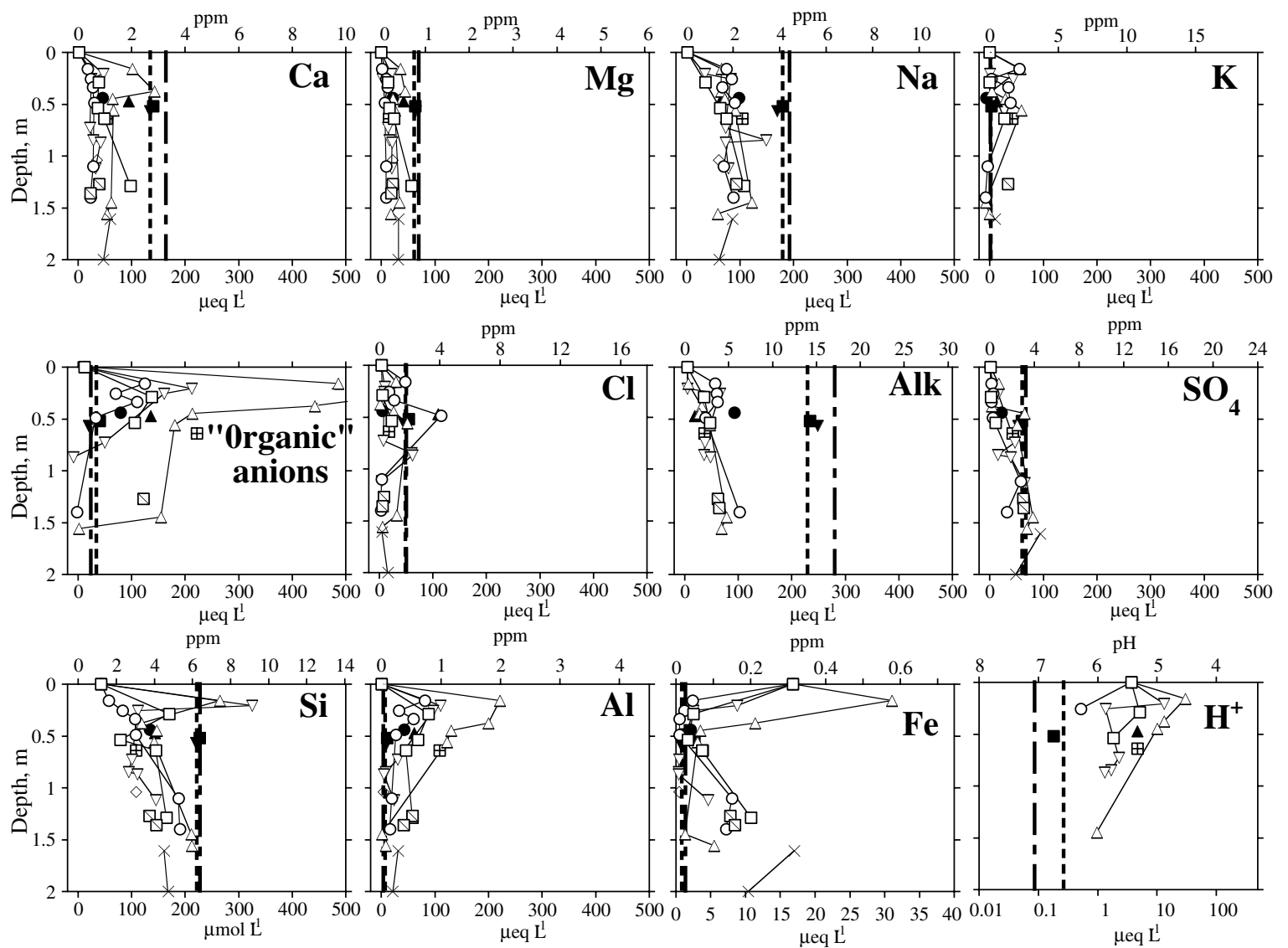

Figure 8. Solute concentrations in lysimeter and runoff samples on 31 May, during the steady-discharge period of sprinkling experiment 3. Rainwater concentrations are the top point in each profile. Symbols are as in Figures 5 and 6. 'Organic' anion equivalents in the lysimeter at $0.38 \mathrm{~m}$ depth in the nest at row 6 plots off scale at $626 \mu \mathrm{eq} \mathrm{1}^{-1}$. Note that all plots, except for hydrogen ions and iron, use the same scale across the bottom in $\mu$ eq $1^{-1}$, and that the hydrogen ion plot uses a logarithmic scale

Most of the temporal variations in soil water chemistry occurred during wetting-up. Chloride (Figure 5), 'organic' anion equivalents, calcium, and potassium displayed high concentrations in the shallow lysimeters during transient flow conditions (Anderson, 1995). The concentrations of these species declined through the transient flow period, but water with high solute concentrations does not appear to have been advected down through the colluvium. The concentration gradients stabilized once steady flow conditions began on 30 May. Other species show very little difference between concentration profiles under transient flow conditions and steady flow conditions. The primary exception to these behaviours was silica, for which the initial soil water concentration gradients were disrupted by the rainfall inputs of silica.

Steady water compositions during the steady flow conditions (order $30-130 \mathrm{~mm} \mathrm{day}^{-1}$ ) of the sprinkling experiment imply that the soil water is undergoing steady-state chemical evolution (Reardon, 1981), in which the exchangeable ions along a flow path are in equilibrium with the water chemistry set by mineral weathering reactions. Because the exchange complex is in equilibrium with the water chemistry, the soil water profiles can be interpreted in terms of weathering fluxes from the soil. Steady-state chemical evolution implies that weathering reactions (mineral dissolution, redox reactions) are fast enough to keep up with the solute removal rates imposed by water flux through the soil. Although we have not sampled under a range of flow rates, it appears that the soil water composition for many species is independent of flow rates. If this is correct, the 
flux of solute out of the soil is set by the water flux rather than weathering rates, at least up to some upper value when weathering kinetics becomes limiting.

\section{Runoff chemistry}

Runoff from the CB1 catchment comes almost entirely from water that has travelled through the bedrock. Not surprisingly, therefore, solute concentrations in the runoff at the two weirs, shown with heavy dotted and dashed vertical lines on the soil water profile figures (Figures 5,6 and 8), differed from the soil waters. A comparison of deep lysimeter and runoff compositions shows that bedrock is releasing calcium, sodium, and alkalinity, and a small amount of silica. Conversely, potassium, aluminium, iron, and hydrogen ions were all more concentrated in soil water than in runoff.

Organic anion concentrations are low at the base of the soil and in the runoff, and, therefore, these do not play a role in driving the weathering reactions in the bedrock. Instead, the pattern of high alkalinity and base cations, coupled with some silica release, is consistent with the runoff containing the products of $\mathrm{H}_{2} \mathrm{CO}_{3}$-mediated weathering of silicate minerals and of dissolution of carbonate (Drever, 1997). To test the relative importance of carbonates and silicates to the solute flux we constructed a simple two-reaction mass balance analysis of weathering within the bedrock (Table III).

We calculated bedrock-derived solutes by differencing concentrations in the deepest soil lysimeter from those in the runoff. The sources of this solute were then estimated as follows. Seasalt contributions were determined by balancing all chloride with sodium. We represented silicate weathering as An50 feldspar altering to kaolinite. This feldspar composition is compatible with measured $\mathrm{Ca} / \mathrm{Na}$ ratios in the bedrock at the site (Anderson, 1995). The solute production from this reaction was balanced on silica or sodium, depending on which was limiting. Finally, remaining calcium and alkalinity were attributed (in balance proportions) to carbonate dissolution. The residual shown in Table III is due to solutes unaccounted for in this scheme.

The mass balance shows that, on average, $26 \%$ of the solutes from the bedrock can be attributed to carbonate dissolution (Table III). This is roughly ten times more than would be predicted from the abundance of carbonate in the bedrock. A few percent by volume of the fresh parent rock has carbonate cement, and some carbonate veins are found in fresh parent rock. Both carbonate veins and cement are absent in the weathered rock and soil. Carbonates contribute to solute fluxes out of proportion to their abundance in rock in many settings. Soluble minor phases play important roles in setting solute fluxes most often in environments where physical processes continually expose fresh surfaces to weathering (Blum et al., 1998; White et al.,

Table III. Mass balance analysis of solute production in the bedrock

\begin{tabular}{lcccc}
\hline Lysimeter nest $^{\mathrm{a}}$ & \multicolumn{4}{c}{ Percent of solutes derived from } \\
\cline { 2 - 5 } & Seasalt & An50 & Carbonate $^{\mathrm{c}}$ & Residual $^{\mathrm{d}}$ \\
\hline Row 5 & 13 & 64 & 13 & 10 \\
Row 6 & 15 & 9 & 56 & 19 \\
Row 9A & 17 & 33 & 40 & 11 \\
Row 9B & 14 & 59 & 14 & 14 \\
Row 11A & 12 & 74 & 6 & 8 \\
Row 11B & 14 & 56 & 25 & 5 \\
Average & 14 & 49 & 26 & 11 \\
\hline
\end{tabular}

\footnotetext{
${ }^{a}$ Deepest lysimeter in the nest defines the input concentrations into the bedrock, whereas upper weir runoff defines the output concentrations.

${ }^{\mathrm{b}} \mathrm{Na}_{0.5} \mathrm{Ca}_{0.5} \mathrm{Al}_{1.5} \mathrm{Si}_{2.5} \mathrm{O}_{8}+1.5 \mathrm{H}_{2} \mathrm{CO}_{3}+0.75 \mathrm{H}_{2} \mathrm{O}=0.5 \mathrm{Na}^{+}+0.5 \mathrm{Ca}^{2+}+1.5 \mathrm{HCO}_{3}{ }^{-}+$ $\mathrm{SiO}_{2}+0.75 \mathrm{Al}_{2} \mathrm{Si}_{2} \mathrm{O}_{5}(\mathrm{OH})_{4}$

${ }^{\mathrm{c}} \mathrm{CaCO}_{3}+\mathrm{H}_{2} \mathrm{CO}_{3}=\mathrm{Ca}^{2+}+2 \mathrm{HCO}_{3}{ }^{-}$.

${ }^{\mathrm{d}}$ Residual consists of solutes not accounted for in the two reactions and seasalt correction.
} 
1999; Anderson et al., 2000). In the CB1 catchment, it is likely that opening of fractures provides avenues to fresh bedrock to begin this cascade of weathering processes.

Temporal variations in runoff chemistry. Changes in concentration of solutes with discharge are commonly observed and typically interpreted as reflecting changes in water sources (Bricker et al., 1968; Christophersen et al., 1982; Johnson et al., 1969; Kennedy, 1971). During sprinkling experiment 3, every solute except hydrogen ions and silica declined in concentration in the runoff at the two weirs as the discharge increased (Figure 9). Hydrogen ion concentration showed the opposite trend, and was positively correlated with discharge. Silica decreased with increasing discharge at the upper weir, but showed initial increases in concentration at the lower weir. Concentrations of all species tended to level off at steady discharge, and to climb as the discharge fell at the end of the experiment, although they did not recover to pre-experiment levels as rapidly as the discharge. This temporal pattern of concentration variations with discharge during experiment 3 was also observed in sprinkler experiments 1 and 2, conducted 2 years earlier with untreated pond water used for irrigation. Despite the untreated water used in experiments 1 and 2 and the demineralized water used in experiment 3 , there are very few differences in the runoff chemistry during the steady discharge periods of these experiments (Anderson et al., 1997b).

Two mechanisms probably drive the reduction in solute concentrations with increased discharge: changes in water sources and changes in water contact time in the bedrock. First, contributions of dilute water from the soil directly to the runoff, without routing through the bedrock, are possible only when a zone of subsurface saturation develops in the colluvium during rainfall. As this subsurface variable source area grows during
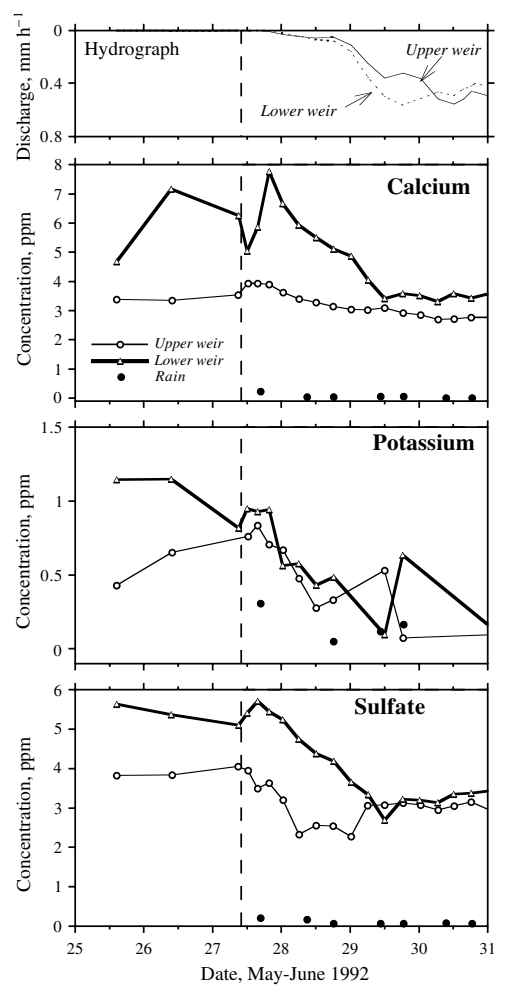
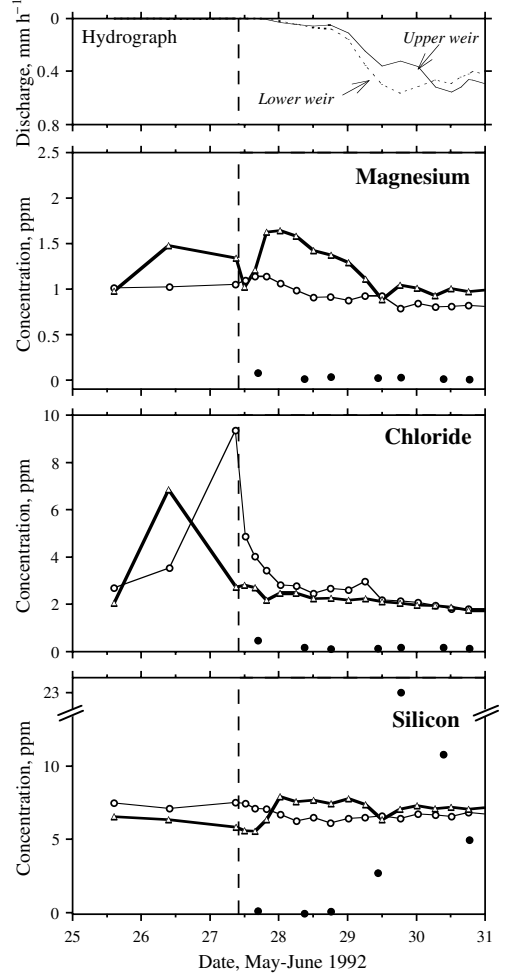
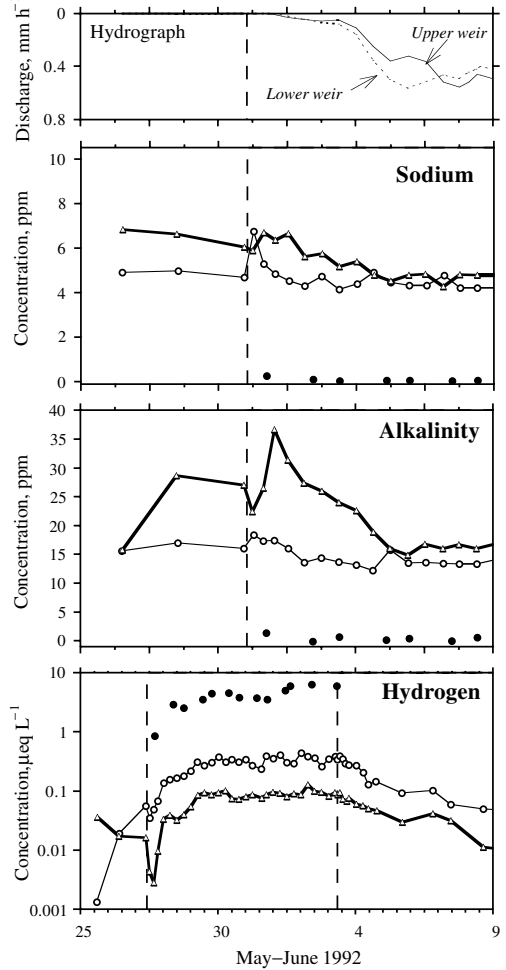

Figure 9. Concentrations of dissolved species in the runoff at the two weirs during the early part of sprinkler experiment 3. Upper weir concentrations shown with open circles; lower weir concentrations with open triangles. Concentrations in the precipitation are shown with unconnected filled circles. Hydrographs for the weirs shown in the top panel of each column. The beginning of the sprinkler runs for experiment 3 shown with thin dashed vertical lines 
rainfall, the direct contribution of low solute soil water to runoff increases. Second, increased saturation within the bedrock could fill partially saturated fractures, and allow low concentration water derived from the soil to move through the bedrock rapidly and without significant chemical interaction. This mechanism would explain the low calculated concentration of water emerging from the bedrock $C_{\mathrm{R}}$ at steady discharge (Equation (12)), compared with the concentration of entirely bedrock-derived water at low discharge. Note that in neither mechanism is the dilution of runoff with increasing discharge caused directly by new water. Rather, new rain pushes water through the soil and rapidly through the bedrock, increasing the transit of low concentration soil water out of the catchment.

Contact time appears to be of greater importance in setting solute concentrations in the bedrock than in the soil. We have seen that soil waters vary in ionic composition, but not TDS concentration, with increased depth in the soil. Once the initial, change-in-storage-driven dilution of soil water had taken place in the first few days of the sprinkling experiment, solute compositions remained fairly steady in the soil, and concentration gradients were maintained. Initial high concentrations in shallow soil probably are the result of evaporative concentration rather than long contact time. These observations suggest that contact time has little to do with solute concentrations within the soil, as perhaps should be expected in a system with a large exchange complex. The bedrock, however, lacks a large exchange complex, probably due to lack of organic material, which allows for more variation in solute concentrations.

The concentrations of many species in the runoff did not change monotonically with increasing discharge during the first hours of sprinkling experiment 3. Most solute concentrations rose during the first 2 to $14 \mathrm{~h}$ of sprinkling to a maximum value before declining to steady discharge levels (Figure 9). Some species displayed more complex behaviour: at the lower weir, calcium and alkalinity fell initially, then rose to a maximum, and then declined to their steady discharge concentrations. Generally, the time from start of sprinkling to the maximum concentration was longer at the lower weir than the upper weir, and the magnitude of the shift from pre-sprinkling concentrations to the maximum concentration was greater at the lower weir. Similar initial concentration increases were noted during experiments 1 and 2 (Anderson et al., 1997b).

The discharge during these transient concentration trends had reached only 5\% of the steady state discharge. Most of the concentration maxima were reached in $5.75 \mathrm{~h}$, when the discharge had increased from $0.0038 \mathrm{~mm} \mathrm{~h}^{-1}\left(0.9 \mathrm{ml} \mathrm{s}^{-1}\right)$ to $0.0046 \mathrm{~mm} \mathrm{~h}^{-1}\left(1.1 \mathrm{ml} \mathrm{s}^{-1}\right)$, a mere $0.4 \%$ of the steady-state discharge. An explanation for these transients requires a source of high concentration water that is mobilized out of the catchment very soon after the onset of rain. One possibility is that new rain falling on the catchment very rapidly alters the flow dynamics throughout the soil and bedrock and causes water that had been in storage, on mineral surfaces, in small pores, in micro-fractures, or in dead-end pores, to move out of the catchment. These small pores have a greater mineral surface area to water volume, which would lead to higher solute content than water in larger pores. Torres (1997) amassed evidence for a pressure wave passing through the soil at the onset of sprinkling at a rate that exceeded the advancement of water through the catchment; this may provide the impetus to mobilize stored solute-laden water out of the catchment rapidly.

\section{Water storage}

With the data in hand from the CB1 catchment, it is impossible to unravel whether the solute loads in the water exfiltrating from the bedrock result from rapid kinetics or from partial flushing of a reservoir of high concentration water stored in the bedrock. The solute concentrations in the bedrock-exfiltration-fed lysimeters $0-2 z$ and $1-1 C$ fell by only a few percent during the course of the sprinkling experiment, and runoff chemistry was similarly steady during the steady discharge portion of the experiment. This suggests that either the kinetics of weathering reactions in the bedrock are rapid, and water equilibrates with the bedrock during the time it passes through the rock, or that the reservoir of water in the bedrock is much greater than could be flushed out by the $274 \mathrm{~mm}$ of rain applied during sprinkling experiment 3 .

The potential for water storage in the bedrock is quite high, and was not considered in the colluvium water balance earlier. Weathered and fractured rock extends to a depth of $9 \mathrm{~m}$ at the top of the catchment (Figure 1). 
These layers thin downslope, but are still $3 \mathrm{~m}$ thick near the channel head at the upper weir. Although we were unable to drill on the interfluve noses at the edge of the catchment, we speculate that weathered rock layers thin away from the catchment axis (Reneau and Dietrich, 1991). The porosity in the bedrock core calculated from measured bulk density and grain density was $12 \pm 3 \%$, with slightly higher values in the pervasively oxidized and the fractured rock layers than in the unweathered rock below. These values are typical for fine-grained sandstone (Freeze and Cherry, 1979), but do not include fractures, which probably provide most of the hydrologically connected porosity. Fractures generally increase the porosity of rock by $2-5 \%$ (Davis, 1969), therefore, an estimate of the effective porosity is $5 \%$ in weathered rock layers. Using the minimum weathered rock thickness of $3 \mathrm{~m}$ to allow for variable saturation, and $5 \%$ water content, yields an estimated water storage potential of about $150 \mathrm{~mm}$ within the bedrock. The water stored in the rock could be substantially higher if water is stored in the non-fracture porosity in the rock, or if the water table is higher. We have already estimated that the antecedent water in the colluvium is $133 \mathrm{~mm}$, or roughly equivalent to this estimate of water stored in the bedrock.

The total rainfall during experiment 3 was $274 \mathrm{~mm}$. If these estimates of $150 \mathrm{~mm}$ water storage in the rock and $133 \mathrm{~mm}$ water storage in the colluvium are correct, then the sprinkling experiment just displaced the antecedent water stored in the catchment. Given the mean annual runoff of $1.6 \mathrm{~m}_{\text {year }}^{-1}$, the water in the catchment is completely displaced about five times each year, and the mean residence time is on the order of 2 months for an even distribution of rain in the year. The dry summers and wet winters of the Oregon Coast, however, mean that water residence times will depart from the mean over the course of a year.

The average $24 \mathrm{~h}$ rainfall between 1960 and 1990 at the North Bend Airport, located $12 \mathrm{~km}$ from the CB1 catchment, was $10 \pm 13 \mathrm{~mm}$. Thus, the typical rainy day will only displace a few percent of the water stored in the catchment, and it will take a particularly intense and long storm to approach total displacement. The size of the reservoir of water stored in the catchment should provide considerable inertia in the composition of the runoff.

\section{CONCLUSIONS}

The black box of the CB1 catchment has been divided into four discernible weathered layers: colluvial soil, saprolite, pervasively oxidized rock, and fractured, partially oxidized rock. Water percolates vertically through the colluvial soil and flows laterally toward the catchment outlet through the three weathered rock layers; wet conditions allow a small portion to return periodically to the colluvium mantle and then reinfiltrate into the rock as it travels downslope. Under conditions of high flow a small fraction of the runoff $(\mathrm{ca} 7 \%)$ passes through the catchment without encountering bedrock. Yet, the flux of solutes derived from mineral weathering in the soil during the steady high flow conditions of sprinkling experiment 3 equalled the flux of solutes derived from mineral weathering in the bedrock. The lack of correspondence between the partitioning of water and solute sources in the runoff suggests that water flow through the bedrock under conditions of high flow is too rapid to acquire substantial solute concentrations. Contact time appears, therefore, to be an important control on solute concentrations in waters in the bedrock. The average thickness of the weathered rock layers $(>3 \mathrm{~m})$ in the catchment is much greater than the average thickness of the colluvium $(0.7 \mathrm{~m})$, and, therefore, the equal partitioning of weathering-derived solutes from the bedrock and soils implies that the intensity of weathering processes on a per-unit-volume basis is greater in the soils.

Within the soil, leaching of organic matter yielded high 'organic' anion concentrations at shallow depths, and appears to promote the process of podzolization. The high 'organic' anion concentrations were associated with elevated concentrations of aluminium and iron, indicative of this important pedogenic process. Spatial variability in the concentrations of these solutes in the catchment, and the lack of spodic horizon development in the $\mathrm{CB} 1$ catchment soils are attributed to the effects of bioturbation, which disrupts soil horizons and alters litter distribution at the soil surface. 
Differences in soil water and runoff chemistry suggest that silicate weathering reactions are the predominant chemical processes within the soil, whereas carbonate dissolution plays a role in the bedrock.

Solute concentrations in the runoff vary inversely with discharge. At low flow, the runoff is derived entirely from bedrock exfiltration, and the solute concentrations are highest. At high flow, a small portion $(\sim 7 \%)$ of the water passes directly from the soil to the catchment outlet, without encountering bedrock. Though this low solute water contributes to the lowered concentrations in runoff at high flow, water and solute balances show that the concentration of water exfiltrating from the bedrock is reduced under high flow conditions as well. Rapid flow through bedrock fractures with minimal contact with the rock is a likely mechanism for the reduction in solute concentrations in water exfiltrating from the bedrock. Together, these effects lead to the reduction of solute concentration with increasing discharge.

Water storage in the drained colluvium of the CB1 catchment can be reasonably estimated at $133 \mathrm{~mm}$. A less well constrained estimate of water stored in the bedrock is $150 \mathrm{~mm}$. Thus, the total storage within the catchment is approximately $280 \mathrm{~mm}$, or about $20 \%$ of the mean annual runoff of $1.6 \mathrm{~m}$. This implies that the mean residence time for water in the catchment is 2 months, and that typical rainstorms of $10 \mathrm{~mm} \mathrm{day}^{-1}$ will displace only a few percent of the water stored within the catchment. The slow displacement of old water from the catchment provide considerable inertia to the composition of runoff, and results in the low slope of the TDS against discharge.

The solute concentration from the catchment during the steady flow period of the sprinkling experiment and the average annual discharge yields a chemical denudation rate of $32 \pm 10 \mathrm{t} \mathrm{km}^{-2}$ year ${ }^{-1}$ (bedrock lowering of $14 \pm 4 \mu \mathrm{m} \mathrm{year}^{-1}$ ). This is the same as the chemical denudation rate Dethier (1986) calculated from solute loads of rivers draining the Oregon Coast Range. The close correspondence between the rate based on a single sprinkling experiment and that based on annual solute loads in large rivers suggest two things. First, the variations in concentration with discharge play only a minor role in setting the solute fluxes out of the catchment. Although solute concentrations are higher at lower discharge, these discharges contribute very little to the solute flux from the catchment. Second, the chemical denudation rate does not change substantially over the six orders of magnitude in basin size spanned by the $860 \mathrm{~m}^{2} \mathrm{CB} 1$ catchment to the $122 \mathrm{~km}^{2}$ Millicoma and $1523 \mathrm{~km}^{2}$ Siuslaw rivers studied by Dethier (1986). This suggests that understanding weathering in a small-scale catchment captures the essence of the role of weathering in the landscape.

\section{ACKNOWLEDGEMENTS}

We would like to thank the others who worked at the CB1 catchment with us, particularly D.R. Montgomery, R. Torres, K. Loague and T. Giambelluca. We appreciated the insightful comments by T. Tanaka and an anonymous reviewer. We thank Jeff McDonnell and Tadashi Tanaka for the invitation to present this work at the joint Japan-USA seminar on the hydrology and biogeochemistry of headwater catchments. This work was supported by a NASA fellowship to S.P.A. Institute of Tectonics contribution number 422.

\section{REFERENCES}

Anderson SP. 1995. Flow paths, solute sources, weathering, and denudation rates: the chemical geomorphology of a small catchment. PhD thesis, U.C. Berkeley.

Anderson SP, Dietrich WE, Montgomery DR, Torres R, Conrad ME, Loague K. 1997a. Subsurface flow paths in a steep unchanneled catchment. Water Resources Research 33: 2637-2653.

Anderson SP, Dietrich WE, Torres R, Montgomery DR, Loague K. 1997b. Concentration-discharge relationships in a steep, unchanneled catchment. Water Resources Research 33: 211-225.

Anderson SP, Drever JI, Frost CD, Holden P. 2000. Chemical weathering in the foreland of a retreating glacier. Geochimica et Cosmochimica Acta 64: 1173-1189.

Baldwin EM. 1974. Eocene stratigraphy of southwestern Oregon. Oregon Department of Geology and Mineral Industries Bulletin no. 83, 40 pp.

Baldwin EM. 1975. Revision of the Eocene stratigraphy of southwestern Oregon. In Paleogene Symposium and Selected Technical Papers, WeaverDW, Hornaday GR, Tipton A (eds). AAPG: Long Beach, CA; 49-64. 
Beck MB, Kleissen FM, Wheater HS. 1990. Identifying flow paths in models of surface water acidification. Reviews of Geophysics 28: 207-230.

Birkeland P. 1999. Soils and Geomorphology, 3rd edn. Oxford University Press.

Blum JD, Gazis CA, Jacobson AD, Chamberlain CP. 1998. Carbonate versus silicate weathering in the Raikhot watershed within the High Himalayan Crystalline Series. Geology 26: 411-414.

Bricker OP, Godfrey AE, Cleaves ET. 1968. Mineral-water interaction during the chemical weathering of silicates. In Trace Inorganics in Water, Baker RA (ed.). vol. 73 of Advances in Chemistry Series. American Chemical Society: 128-142.

Buol SW, Hole FD, McCracken RJ. 1980. Soil Genesis and Classification. The Iowa State University Press: Ames, IA; 406 pp.

Christophersen N, Seip HM, Wright RF. 1982. A model for streamwater chemistry at Birkenes, Norway. Water Resources Research 18: 977-996.

Dahlgren RA, Ugolini FC. 1989. Aluminum fractionation of soil solutions from unperturbed and tephra-treated spodosols, Cascade Range, Washington, U.S.A. Soil Science Society of America Journal 53: 559-566.

Davis SN. 1969. Porosity and permeability of natural materials. In Flow Through Porous Media, De Wiest RJM (ed.). Academic Press: New York; 54-89.

Dethier DP. 1986. Weathering rates and the chemical flux from catchments in the Pacific Northwest, USA. In Rates of Chemical Weathering of Rocks and Minerals, Colman SM, Dethier DP (eds). Academic Press: Orlando; 503-530.

Dott Jr RH. 1966. Eocene deltaic sedimentation at Coos Bay, Oregon. Journal of Geology 74: 373-420.

Drever JI. 1997. The Geochemistry of Natural Waters: Surface and Groundwater Environments. Prentice Hall: Englewood Cliffs, NJ; 436 pp.

Drever JI, Clow DW. 1995. Weathering rates in catchments. In Chemical Weathering Rates of Silicate Minerals, White AF, Brantley SL (eds). vol. 31, Reviews in Mineralogy: Mineralogical Society of America: Washington, DC; 463-483.

Driscoll CT, van Breemen N, Mulder J. 1985. Aluminum chemistry in a forested Spodosol. Soil Science Society of America Journal 49: 437-444.

Freeze RA, Cherry JA. 1979. Groundwater. Prentice-Hall: Englewood Cliffs, NJ; 604 pp.

Garrels RM, Mackenzie FT. 1967. Origin of the chemical compositions of some springs and lakes. In Equilibrium Concepts in Natural Water Systems, American Chemical Society Advanced Chemistry Series 67. ACS; 222-242.

Gran G. 1952. Determination of the equivalence point in potentiometric titrations, part II. The Analyst 77: 661-671.

Haagen JT. 1989. Soil Survey of Coos County, Oregon. US Department of Agriculture, Soil Conservation Service; 269 pp.

Johnson NM, Likens GE, Bormann FH, Fisher DW, Pierce RS. 1969. A working model for the variation in stream water chemistry at the Hubbard Brook Experimental Forest, New Hampshire. Water Resources Research 5: 1353-1363.

Kennedy VC. 1971. Silica variation in stream water with time and discharge. In Nonequilibrium Systems in Natural Water Chemistry. Hem JD (ed.). vol. 106, Advances in Chemistry Series. American Chemical Society: 94-130.

Lovell JPB. 1969. Tyee Formation: undeformed turbidites and their lateral equivalents: mineralogy and paleogeography. Geological Society of America Bulletin 80: 9-22.

Luxmoore RJ. 1981. Micro-, meso-, and macroporosity of soil. Soil Science Society of America Journal 45: 671-672.

MacDonald LH. 1988. An inexpensive, portable system for drilling into subsurface layers. Soil Science Society of America Journal 52: $1817-1819$.

Miller WR, Drever JI. 1977. Water chemistry of a stream following a storm, Absaroka Mountains, Wyoming. Geological Society of America Bulletin 88: 286-290.

Montgomery DR. 1991. Channel initiation and landscape evolution. PhD thesis, University of California, Berkeley.

Montgomery DR, Dietrich WE, Torres R, Anderson SP, Heffner JT, Loague K. 1997. Hydrologic response of a steep, unchanneled valley to natural and applied rainfall. Water Resources Research 33: 91-109.

Pavich MJ. 1986. Processes and rates of saprolite production and erosion on a foliated granitic rock of the Virginia Piedmont. In Rates of Chemical Weathering of Rocks and Minerals, Colman SM, Dethier DP (eds). Academic Press: Orlando; 551-590.

Reardon EJ. 1981. $K_{\mathrm{d}}$ 's - can they be used to describe reversible ion sorption reactions in contaminant migration? Ground Water 19(3): $279-286$

Reneau SL, Dietrich WE. 1990. Depositional history of hollows on steep hillslopes, coastal Oregon and Washington. National Geographic Research 6: 220-230.

Reneau SL, Dietrich WE. 1991. Erosion rates in the southern Oregon Coast Range: Evidence for an equilibrium between hillslope erosion and sediment yield. Earth Surface Processes and Landforms 16: 307-322.

Stumm W, Morgan JJ. 1981. Aquatic Chemistry. John Wiley \& Sons: New York; 780 pp.

Torres R. 1997. Unsaturated zone processes and the hydrologic response of a steep, unchanneled valley. PhD thesis; University of California, Berkeley.

Torres R, Dietrich WE, Loague K, Montgomery DR, Anderson SP. 1998. Unsaturated zone processes and the hydrologic response of a steep, unchanneled catchment. Water Resources Research 34: 1865-1879.

Trudgill S, Wise S. 1997. Long-term spatially distributed solutional erosion: how do we put solutes on the map? Earth Surface Processes and Landforms 22: 281-285.

Ugolini FC, Dahlgren R. 1987. The mechanism of podzolization as revealed by soil solution studies. In Podzols et Podzolization, Righi D, Chauvel A (eds). AFES et INRA (Association Française pour l'Étude du Sol et Institut National de la Recherche Agronomique): Paris; 195-203.

White AF, Bullen TD, Vivit DV, Schulz MS, Clow DW. 1999. The role of disseminated calcite in the chemical weathering of granitoid rocks. Geochimica et Cosmochimica Acta 63: 1939-1953. 